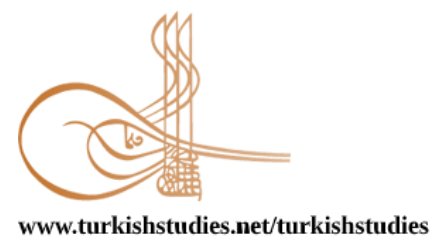

Turkish Studies

\title{
Uluslararası Havayolları Şirketlerinin Covid-19 Salgını Sürecinde Instagram'da Marka İletişimi Stratejilerinin Analizi
}

\author{
Analysis of Brand Communication Strategies of International Airline Companies in Instagram \\ During Covid-19 Outbreak Process
}

\author{
Zeynep Benan Dondurucu* - Aysel Çetinkaya*
}

\begin{abstract}
During the Covid-19 epidemic period, international airline companies faced customer relations problems due to travel restrictions of countries, delayed flights and financial problems when the spread of the disease increased starting from the period of March 2020. The pandemic turned into a crisis for the airline industry in a short time. For this reason, the importance of the social media platforms they use for interactive brand communication activities in the pre-crisis period has increased for the airline companies. This study uses Instagram as a research platform. While the visual-weighted structure of Instagram provides the brands the opportunity to reflect their personality and apply different brand communication strategies, it offers easy access to interesting content and representatives of global brands for consumers. Since social media usage level and brand-follower interaction increased globally due to the Covid-19 pandemic process, the importance of Instagram increased correspondingly. Therefore, this study aims to compare Instagram strategies of national airline companies of the United States, Britain with Turkish Airlines (national airline company of Turkey) during the Covid-19 epidemic process (pre-crisis and crisis periods). Airline companies in USA and Britain will likely be effected more negatively because of high number of cases and high death rate in USA and Britain, that is why this study selected these countries for comparison. For this purpose, the content on the Instagram pages of Turkish Airlines, British Airways and American Airlines companies were analyzed by qualitative and quantitative content analysis method starting from the date that the World Health Organization announced the existence of a new virus emerging in China to the world publicly, until the gradual normalization process. The research model has been formed in a mixed way, based on various researches conducted in the literature. The study formed content analysis categories such as brand communication strategies implemented by international airline companies before and during the crisis, special strategies applied for the Covid-19 era, brand personality dimensions, specific brand connotations for the Covid-19 outbreak, formal structure features and level of interaction change. As a result, the research has found that the content sharing levels of Turkish Airlines and American Airlines companies in Instagram
\end{abstract}

* Arș. Gör. Dr., Kocaeli Üniversitesi, İletișim Fakültesi, Halkla İlişkiler ve Tanıtım Bölümü Res. Asst. PhD., Kocaeli University, Communication Faculty, Departmant of Public Relations and Publicity ORCID 0000-0002-2634-1001

zdondurucu@yahoo.com

* Dr. Öğr. Üyesi, Kocaeli Üniversitesi, İletişim Fakültesi, Gazetecilik Bölümü Asst. Prof. Dr., Kocaeli University, Communication Faculty, Departmant of Journalism ORCID 0000-0003-2526-323X

ayselctnky@gmail.com

Cite as/ Atıf: Dondurucu, Z. B., Çetinkaya, A. (2020). Uluslararası havayolları şirketlerinin Covid-19 salgını sürecinde Instagram'da marka iletişimi stratejilerinin analizi. Turkish Studies, 15(4), 325-356. https://dx.doi.org/10.7827/TurkishStudies.44479

Received/Geliş: 23 June/Haziran 2020

Accepted/Kabul: 10 August/Ağustos 2020

Copyright (C) MDE, Turkey

Checked by plagiarism software

Published/Yayın: 30 August/Ağustos 2020

CC BY-NC 4.0 
increased during the crisis period and the number of messages of British Airways decreased. In addition, the brand communication strategies and ways of reflecting brand personalities of the airline companies differed in the pre-crisis and post-crisis period. Another important finding of the research is that Turkish Airlines and American Airlines, which increased the content sharing level during the epidemic, achieved higher interaction compared to British Airways, which had limited communication. This result reveals the importance of maintaining brand communication activities in social media during times of crisis.

\section{Structured Abstract: Introduction}

Aviation ranks first in the sectors affected by the Covid-19 outbreak, which started in China in December 2019 and spread worldwide. With the transformation of the epidemic into a crisis, it has become more important for airlines to use social media platforms effectively to minimize loss by communicating with potential consumers, informing followers, and maintaining the best customer experience. Instagram has advantages such as attracting the attention of consumers, creating interactions, reflecting their personalities for brands, enabling the implementation of different brand communication strategies with its visual-weighted structure (Çetinkaya and Özdemir, 2012: 590, Ginsberg 2015: 80, Goor, 2012: 31). Due to these reasons, this study analyzed the Instagram shares of the airline companies comparatively before and during the crisis, and tried to reveal the transformation of the presentation of brand communication strategies and brand personality traits.

\section{Purpose}

This study aims to inform about the general and Covid-19 messages in the Instagram accounts of Turkish Airlines (THY), American Airlines (AA) and British Airways (BA) during the period and the crisis before the Covid-19 disease turned into a crisis. This study analyzed the brand communication strategies specific to the period, their formal structure, level of interaction, brand personality dimensions and brand connotations based on Covid-19 comparatively.

\section{Method}

The sample of this study included the content shared in the Instagram accounts of Turkish Airlines, American Airlines and British Airlines companies before and during the Covid-19 period. The main reasons for these choices were the fact that the crisis had a major effect on the airline industry during the pandemic process, the highest incidence and mortality rates were in the USA and the UK during the review period, selected airline companies had the most international flight routes. The time interval of the research is limited to the date of January 5, 2020, when the World Health Organization announced to the global media about the new virus outbreak in China, and the countries entered into a gradual normalization process. The study carried out qualitative and quantitative (interaction level) content analysis was for the messages in the Instagram accounts of international airlines. The codes/categories can be created according to the subject studied in the content analysis method. Accordingly, the study has developed a new research model based on the classification of brand communication strategies on Instagram of Vasollo et al. (2018: 3), the research on brand contents on social media of Tafesse and Wien (2017: 10), Typology of Wattanacharoensil and Schuckert (2015: 661-671) to create interaction on airports' social media, encoding communication strategies of brands on social media in times of crisis of Han, Hi Sung and Hoo Kim (2017: 817-818), brand personality dimensions classification of Aaker (1997), the typology of brand personality dimensions of airline companies of Cervera-Taulet et al. (2013: 449), emotions (brand connotations) that brands have on consumers and the new brand personality dimensions transferred to social media during the epidemic process of Covid-19 of Sheridan et al. (2020: 6).

\section{Results}

The research concluded that all airline companies, except British Airways, used the media effectively in order to keep the interaction with their potential customers/followers in line with the increase in the number of content they shared during the epidemic periodIn terms of the use of brand communication strategies, all three brands shared informative content in line with the increasing information needs of the consumer, unlike the pre-Covid-19 epidemic period. In addition, brands expanded their image-oriented brand communication strategies in Instagram shares, by focusing on variables such as personnel, consumer and social responsibility during the epidemic. The study found that the airlines used positive brand communication strategy in the first place in the Instagram posts specifically for the Covid-19 period. All three brands implemented special strategies such as offering solutions to the consumer and supporting the

Turkish Studies, 15(4) 

327

process by fulfilling their responsibilities. However, THY's lack of social responsibility-based collaboration shares on Instagram, unlike the other two brands examined, constitutes a basic deficiency in terms of meeting the increasing expectations of the society from economic enterprises during the epidemic period. In the crisis period, the brand personality dimensions reflected on the Instagram pages of all three brands included more "competence" and "sincerity" dimensions compared to the pre-pandemic period. This result reveals that all airline companies managed the process correctly, depending on the demand of the society to perform reliable, institutional and responsible behaviors in times of crisis and the rise of national emotions/community/community awareness. The determination of private brand connotations, such as power, security, positivity, and reliability, in varying proportions of brands in Instagram accounts during the pandemic period, reveals that the airline companies fulfill the relevant/helpful role that the society expects of them. The research concluded that the company with the highest level of engagement/display/comment interaction was THY and the lowest company was British Airways, both in the pre-epidemic period and during the epidemic. While the interaction of all airline companies increased during the epidemic period, the low number of content of British Airways caused to not be able to take full advantage of the interactive structure of the medium and to continuously implement the brand communication strategies needed to connect with consumers. In this context, businesses operating in sectors such as the airline, which has a high level of influence in times of crisis that threaten the health and well-being of the entire society, such as the Covid-19 outbreak, should actively use platforms such as Instagram that allow to reflect brand personality and use different brand communication strategies. Also, it would be appropriate to restructure the brand communication strategies and associations in a way that would increase the follower interaction in the content shared. This research will guide other studies aimed at identifying the usage of Instagram or other social media platforms of other sectors and other airlines affected by the Covid-19 crisis in the pre-crisis, post-crisis periods.

Keywords: social media, Instagram, brand communication strategies, brand personality, crisis communication

Öz: Covid-19 salgını döneminde, ülkelerin seyahat kısıtlamaları nedeniyle, hastalı̆ı̆ı yayılım hızının yükseldiği Mart 2020 döneminden başlayarak uluslararası hava yolu şirketleri; finansal sorunlar ve uçuşların ertelenmesine bağlı olarak müşteri ilişkileri problemleriyle karşı karşıya kalmıştır. Pandemi dönemi, hava yolu sektörü için kısa sürede bir krize dönüşmüştür. Bu nedenle, hava yolu şirketleri için kriz öncesi dönemde etkileşimli marka iletişim çalışmaları için kullandıkları sosyal medya platformlarının önemi artmıştır. Bu çalışmada, araştırma platformu olarak belirlenen Instagram'ın görsel ağırlıklı yapısı, markalar için kişiliklerini yansıtma ve farklı marka iletişim stratejilerini uygulama olanağı sağlarken; tüketiciler için ise ilgi çekici içeriklere ve küresel markaların temsilcilerine kolay erişim imkanı sunmaktadır. Ayrıca, Covid19 pandemisi sürecinde küresel olarak sosyal medya kullanım düzeyinin ve marka-takipçi etkileşiminin yükselmesi; Instagram'ın önemini arttırmışır. Bu nedenle, bu çalı̧̧mada Covid-19 salgını sürecinde (kriz öncesi ve kriz dönemi), vaka sayısı ve ölüm oranlarının fazlalı̆̆ı nedeniyle havacılık sektörünün zarar görmesi daha muhtemel olan Amerika Birleşik Devletleri ve İngiltere'nin ulusal hava yolu şirketlerinin Instagram kullanım stratejilerinin, Türkiye'nin ulusal hava yolu firması olan Türk Hava Yolları ile kıyaslanması amaçlanmıştır. Bu amaçla, Dünya Sağlık Örgütü'nün Çin'de ortaya çıkan yeni bir virüsün varlığını dünya kamuoyuna açıkladığı tarihten başlayarak; kademeli normalleşme sürecine girilen döneme kadar; Türk Hava Yolları, British Airways ve American Airlines şirketlerinin Instagram sayfalarında yer alan içerikler nitel ve nicel içerik analizi yöntemi ile incelenmiştir. Araştırma modeli, alan yazında gerçekleştirilen çeşitli araştırmalar temel alınarak; karma bir biçimde oluşturulmuştur. İçerik analizi kategorileri ise; uluslararası hava yolu şirketlerinin kriz öncesi ve kriz döneminde uyguladıkları marka iletişim stratejileri; Covid-19 dönemi için uygulanan özel stratejiler, marka kişilik boyutları, Covid-19 salgınına özel marka çağrışımları, biçimsel yapı özellikleri ve etkileşim düzeyi değişimini ortaya koyacak biçimde oluşturulmuştur. Araştırma sonucunda, Türk Hava Yolları ve American Airlines firmalarının Instagram'da kriz döneminde içerik paylaşım düzeylerinin yükseldiğgi; British Airways'in ise ileti sayısının azaldığı tespit edilmiş̧ir. Ayrıca, incelenen hava yolu şirketlerinin marka iletişim stratejilerinin ve marka kişiliklerini yansıtma biçimlerinin; kriz öncesi ve kriz döneminde farklılaştığı sonucuna ulaşılmıştır. Araştırmada saptanan bir diğer önemli bulgu ise, salgın sürecinde içerik paylaşım düzeyini yükselten THY ve American Airlines'ın; sınırlı iletişim gerçekleştiren British Airways'e kıyasla daha yüksek etkileşim elde etmesi 
olmuştur. Bu sonuç, kriz dönemlerinde sosyal medyada marka iletişim faaliyetlerini sürdürmenin önemini ortaya koymaktadir.

Anahtar Kelimeler: sosyal medya, Instagram, marka iletişimi stratejileri, marka kişiliği, kriz iletişimi

\section{Giriş}

Aralık 2019'da, Çin'in Wuhan kentinde başlayıp, hızla bütün dünyaya yayılan Covid-19 salgını, uluslararası düzeyde can kayıplarına sebep olmuş ve birçok sektörü durma noktasına getirmiştir. Salgının yayılımını engellemek adına uluslararası ve ulusal düzeyde hava yolu taşımacılığına ara verilmiş, hava yolu şirketleri durumdan en fazla etkilenen kesim olmuştur. Uluslararası Hava Yolu Birliği (Airpot Council International) raporlarına göre; 2019 y1lında hava yolu taşımacılığ 1 sektörü büyüme eğilimi göstermiş, yıl boyunca 9.1 milyar yolcu taşınmış ve toplamda sektörde \%3.4 oranında bir büyüme gerçekleşmiştir. 2020 yılının ilk iki ayında ise, yolcu trafiğinde virüsün Çin'de yayılmaya başlaması ile birlikte Asya-Pasifik hattında düşüş meydana gelmiştir. Ancak, Mart ayında virüsün yayılma hızının yükselmesi; hava yolu taşımacılığı üzerinde önemli olumsuz etkiler oluşturmaya başlamıştır. Önce Avrupa, Orta Doğu ve Kuzey Amerika'dan başlayan, ardından Latin Amerika ve Afrika'ya yayılan pandemi süreci, dünyanın yarısında karantinalara yol açarak; Mart ayının başında küresel yolcu taşımacılığını iki haftalık bir süreyle durdurmuştur. Mart ayının ikinci yarısında ise; büyük hava yolu şirketleri ve farklı ülkeler; ciddi seyahat kısıtlamaları açıklamak durumunda kalmıştır. Pandeminin başlaması ile birlikte; hava trafiğinde yolcu azalma oran1, Ocak ayında \%6.9, Şubat ayında \%22,9 ve Mart ayında \%53.1 olarak açıklanmıştır. Bu sonuçlar, 2020 yılının birinci çeyreğinde, uluslararası yolcu taşıma kapasitesinin bir önceki yıla kıyasla \%28.3 oranında düştüğünü ve 620 milyon yolcu civarında azalma olduğunu göstermektedir (ACI, 2020).

Uluslararası Hava Taşımacılığı Birliği, 05 Mart 2020 tarihinde, salgının başlangıcında hava yolu taşımacılığının 63 ile 113 milyar dolar arası bir kayıp yaşayabileceğini belirtmiştir. Aynı kurum tarafından Nisan ayında yayınlanan bir raporda ise, uluslararası uçuşların \%80 oranında azaldığı, üçüncü çeyrekte sektörün resesyona girmesi sonucu, kaybın 314 milyar doları bulabileceği ifade edilmiştir. Aynı kurumunun 9 Haziran 2020'de yayınladığı "Hava Yolu Sektörünün Ekonomik Performansı" başl1klı raporda ise, Covid-19'un hava yolu taşımacıllı̆̆1 sektörü üzerindeki şu anki etkisinin 84 milyar doları aştığı ve kaybın 2021 yılına kadar devam edebileceği belirtilmiştir (IATA, 2020). Açıklanan tüm bu veriler, hava yolu yolcu taşımacılığı sektörünün içinde bulunduğu zor durumu gözler önüne sermektedir. Tüm bu olumsuzluklara rağmen; uzun bir geçmişe sahip olan markaların hedef kitleleri ile olan bağlarını, kriz dönemlerinde de sürdürmeleri önemlidir. Kotler (2005:31-32), işletmelerin ekonomik durgunluk süreçlerinde maliyet tedbirleri alma amacıyla stratejik ücretli iletişim faaliyetlerinde kısıtlamalara gidildiğini; ancak reklam gibi faaliyetlerle alışılan müşteri deneyiminin ve marka değerinin sürdürülmesi gerektiğini vurgulamaktadır. Kriz dönemlerinde insanların bilgiye olan ihtiyacının arttığı göz önünde bulundurulduğunda, iletişim faaliyetlerine devam eden markaların hedef kitlede olumlu bir alg1 yaratacağı açıktır. Hurk (2013), bir kriz sırasında, işletmelerin tüketicilerin sorularına, ihtiyaçlarına ve endişelerine yanıt vererek; kurumsal itibarlarını potansiyel olarak arttırabileceğini öne sürmektedir. Hız, kapsam ve etki derecesi göz önüne alındığında, sosyal medya platformları kriz dönemlerinde kurumların hedef kitleri ile temas kurduğu en önemli alandır. Kriz dönemlerinde Alexander (2013)'ün vurguladığı üzere; sosyal medya platformlarından kitlenin tartışmalarına kulak verme, durumları izleme, acil durum müdahalesini ve yönetimini genişletme, kalabalık kaynak bulma/işbirlikçi gelişim, sosyal uyum yaratma, sorunlara çözüm bulma ve araştırmay1 geliştirme gibi hususlarda faydalanılmaktadır.

Bu çalışmanın amacı; Covid-19 salgını sürecinde (havayolu krizi öncesi ve kriz dönemi) Türk Hava Yolları (THY), Amerikan Airlines (AA) ve British Airways (BA)'in Instagram 
Uluslararası Havayolları Şirketlerinin Covid-19 Salgını Sürecinde Instagram'da Marka... 329

hesaplarında yer alan paylaşımlarda, genel ve Covid-19 dönemine özel kullandıkları marka iletişimi stratejileri, marka kişilik boyutları ve Covid-19 salgınına özel marka çağrışımlarını tespit ederek; iletilerin biçimsel özellikleri ve etkileşim düzeyleri açısından benzerlik ve farklılıkları incelemektir. $\mathrm{Bu}$ nedenle markaların, 05.01.2020-31.06.2020 tarihleri arasında, Instagram hesaplarında paylaştıkları iletiler, nicel ve nitel içerik analizi yöntemi ile analiz edilmiştir. Böylece, ilgili hava yolu şirketlerinin Covid-19 döneminde değişen marka iletişim stratejileri ve marka kişilik boyutlarının sunumu kriz iletişimi yaklaşımı çerçevesinde; karşılaştırmalı olarak ortaya koyulmuştur.

\section{Kriz Dönemlerinde Stratejik İletişim ve Sosyal Medya Kullanımı}

Kriz dönemleri, kurumların yok olma tehlikesiyle karşı karşıya kaldığı veya doğru yönetildiğinde firsatların yaratıldığı bir süreç olarak karşımıza çıkmaktadır. Krizler, kurum içi nedenlerle gerçekleşebileceği gibi; kurum dışı faktörler veya doğal şartlar nedeniyle de yaşanabilmektedir. Kurumlar, iç kaynaklı krizleri öngörme ve önlemeye dair planlamalar yapabilseler de; salgın hastalık, deprem gibi dışsal çevre kaynaklı krizlere karşı çözüm üretmekte yetersiz kalabilmektedirler.

Kriz, kurumların veya kişilerin var olan konumlarını sarsan, önemli değerleri tehdit eden, kısa zamanda cevap verilmesi gereken ani ve beklenmeyen olaylar olarak tanımlanmaktadır. Her ne kadar ani ve beklenmedik olsa da; kaçınılmaz bir olgu olan krizler; rutin sistemleri bozarak; işletmelerin faaliyetlerini ve yaşamlarını tehdit etmektedir. Bu nedenle, acil müdahale gerektiren krizlerde; bilgi toplama ve karar süreçlerinde yavaş hareket etme, başarı şansını düşürmektedir (Glasscock, 2004: 33; Coombs, 2010:19; Canpolat ve Şahiner, 2017: 214; Akdoğan ve Cingöz, 2009: 6). Krizlerin nedenlerini, kurum içi faktörler ve dış çevre faktörleri olarak ikiye ayırmak mümkündür. Kurumlardaki krize sebep olan iç faktörler arasında; kurumsal yapı özellikleri, üst yönetimin yetersizliği, yönetimin değer ve inançları, bilgi toplama ve işleme yetersizliği, işletmenin geçmişi ve tecrübeleri yer almaktadır (Can, 2005: 392). Krize sebep olan dış çevre faktörler ise, kurumun dışında kalan ve tamamıyla kontrol edilemeyen faktörlerdir. Dış çevrede meydana gelen krizlerin nedenleri; ekonomik, sosyo-kültürel, hukuki-politik, teknolojik çevre, rekabet ortamı değişiklikleri, doğal felaketler ve salgın hastalıklar şeklinde sıralanmaktadır (Dinçer, 1998: 385386; Ataman, 2001: 238). Bu çalışmada incelenen Covid-19 virüsü, sebep olduğu hastalığın bir salgına dönüşmesi nedeniyle, dış çevre kaynaklı krizler sınıfında yer almaktadır. Bu nedenle, hastalığın ortaya çıktığı ülkelerdeki siyasi otoriteler ve kurumlar kriz yönetim stratejileri geliştirmek zorunda kalmıştır. $\mathrm{Bu}$ durumda, krizi etkin bir şekilde yönetebilmek için kullanılabilecek araçlarından en önemlisinin kriz iletişimi olduğu görülmektedir.

Kriz iletişimi uygulamalarında temel amaç ise, krizin işletmeye vereceği zararı en aza indirmektir. Bir defalık stratejik bir tepkiden ziyade; devamlı bir süreç olan kriz iletişiminde; iletişimin zayıflığı koordinasyon ve kontrolü zorlaştırmaktadır (Akdoğan ve Cingöz, 2009: 16-17). Kriz iletişimi sürecinde göz önünde bulundurulması gereken temel prensipler; krizden etkilenecek kişi ve gruplara çabuk ve eksiksiz bilgi vermek, paydaşlarla görüşmeye hazırlıklı olmak/fikir alışverişinde bulunmak/ortak çalışabilmek/iletişimi sürekli tutmak, medya ile işbirlikleri gerçekleştirmek, sorumluluğunu kabul etmek/ görevlerini yerine getirmek olarak sıralanmaktadır (Lukaszewski, 1997: 10-12). Kriz iletişim süreci ise; gözlem, farkında varma, krizi önleme, kriz iletişimine inanma, krize hazırlıklı olmak ve değerlendirme aşamalarından oluşmaktadır (Peltekoğlu, 2007: 450). Geleneksel kriz iletişimi yaklaşımı, paydaşlar ve medya ile doğru ve yapılandırılmış iletişim, iş bölümü ve koordinasyon gibi temeller üzerinde şekillenmekle birlikte; yeni iletişim teknolojilerinin gelişimi kriz iletişimi uygulamalarının dönüşüm geçirmesine neden olmuştur. Özellikle, sosyal medya platformlarının çoklu kullanıcıların anlık ve etkileşimli olarak içerik üretmesine izin veren yapısı; bu mecraların hem krizlerin yayıldığı, hem de yönetilebildiği alanlara dönüşmesine neden olmuştur. 
Sosyal medya, küresel ve yerel düzeyde bilgiye erişimini/paylaşımını kolaylaştırması, düşük maliyetli iletişime ve etkileşime imkan tanıyan yapısı, kolay ölçümleme avantajları ile önemli bir iletişim mecrası haline gelmiştir. Ayrıca, bu platformlara olan ilginin devamlı artması ve farklı kesimlerden çok sayıda kişinin bu mecralar ile bağlantısı; kurumların kriz iletişimi çalışmaları içerisine sosyal medyanın da dahil olmasına neden olmuştur (Bat ve Yurtseven, 2014: 208). Sosyal medyada gerçekleşen tüketici odaklı marka etkileşimi, bazı dönemlerde kurumsal kriz iletişimi amacıyla da kullanılabilmektedir (Roshan vd. 2016). Örneğin; New York La Guardia Havaalanı'nda Southwest Airlines'a ait uçağın burun üstü inmesinin ardından, havayolu şirketi yarım saat sonra sosyal medya üzerinden bir açıklama yaparak, yaşanan gelişmelerle ilgili sürekli bilgi vereceğini taahhüt etmiştir. Firma, sosyal medya aracılığıyla, hedef kitle ile açık ve hızlı iletişim kurarak, halktan önemli destek almış ve krizi başarıyla yönetmiştir (Cohn, 2014).

Sosyal medya, krizlerin toplumsal inşası ve yapı sökümünde giderek daha belirgin bir iletişim aracı haline geldikçe (Schult vd., 2011), bu alandaki araştırmalar da geçtiğimiz on yıllık dönemde artmıştır. Cheng (2016), 2002-2014 tarihleri arası Sosyal Bilimler Atıf Dizini'nde yayınlanan 11 dergide yayınlanan 73 makalede sosyal medyada kriz iletişimi stratejilerini analiz ettiği araştırmasında; etkili kriz iletişim stratejilerini inceleyerek modeller sunmuştur. Wang ve Dong (2017) ise; 2009-2017 yılları arasında 11 iletişim ve halkla ilişkiler dergisinde, sosyal medya merkezli kriz iletişimi araştırmalarında eğilim ve modelleri analiz etmiştir. Çalışma sonucunda, araştırmacılar, sosyal medyada kriz iletişimi çalışmalarının öneminin arttığını ve yeni medyada kriz iletişimi araştırmalarında "içerik analizi" yönteminin sıklıkla kullanıldığı sonucuna ulaşmıştır. Kriz iletişimi araştırmaları, sosyal medyayı krizlerin yayılmasını ve hafiflemesini sağlayan araçlar olarak iki boyutlu bir biçimde ele almaktadır.

Kuruluşlar, bir kriz yaşanmadan önce sosyal medyayı farklı biçimlerde kullanabilmektedirler. Bu kullanım biçimleri arasında, proaktif olarak vatandaşları hazırlıklı hale getirme, bilgi sağlama, uyarılar verme, haberler/güncellemeler sağlama ve kamu güvenliği ile ilgili konularda geri bildirim isteme yer almaktadır (Lindsay, 2011; Veil vd., 2011). Günümüzde, işletmeler, kriz öncesi kurumsal itibar inşası için, sosyal medya platformlarının sağladığı yararları fark ederek, ilişki yönetimi açısından yeni iletişim teknolojileri olanaklarından daha aktif bir biçimde yararlanmaya başlamıştır. Ayrıca, sosyal medya platformları çevresel tarama ve kurumla ilgili tüketici şikayet modellerini belirleme gibi erken dönem kriz işaretlerini tespit amaciyla da kullan1labilmektedir (Ulmer, 2001; Gonzalez-Herrero ve Smith, 2008; Ruggiero ve Vos, 2014).

Kriz öncesi dönemde olduğu gibi, kriz sürecinde de sosyal medya etkin kullanılmakta olup; bu doğrultuda yapılan araştırmalar bulunmaktadır. Kriz dönemlerinde kurumlar, genel olarak sosyal medyayı hedef kitle ile doğrudan diyalog kurma amacıyla kullanmaktadır. Bu kullanım biçimine örnek olarak, Toyota'nın 2010 yılında 2.3 milyon aracı geri çağırmak zorunda kaldığı krizde; paydaşları ile sosyal medya aracıllğıyla iletişim kurması verilebilir (Veil vd. 2011; Auffermann, 2010). Hurk (2013)'e göre, kriz sürecinde doğrudan kamuoyu ile etkileşime giren kuruluşların; tüketicilerin soru, ihtiyaç ve endişelerine yanıt vererek; kurumsal itibarlarını yükseltme potansiyeli bulunmaktadır. Ayrıca, Bridgeman (2008), hız, kapsam ve etki derecesine bağlı olarak; sosyal medyanın bir işletmenin krizi başarılı ya da başarısız yönetme performansının bir göstergesi olduğunu vurgulamaktadır. Ryschka vd. (2016), sosyal medya, kriz yönetimi ve itibar algısını inceleyen araştırmalarında, sosyal medyayı kullanarak kriz sürecinde hızlı yanıt verme potansiyelinin marka bilinirliği üzerinde etkisi olduğu sonucuna ulaşmıştır. Kim vd. (2016) ise; küresel bir e-ticaret sitesi olan Alibaba'nın sosyal medyada içinde bulunduğu itibar krizini çözmek için mizah kullanımının başarısını ölçen bir araştırma gerçekleştirmiştir. Bu araştırmada, saptanan diğer önemli bulgular ise; şirketin en üst düzey yöneticisinin kişiliğinin, para-sosyal ilişkisinin ve kamuoyu araştırmalarının kriz sürecinde kullanımının, sosyal medyaya uygun kriz iletişim stratejileri belirlemenin gerekliliğidir. 
Uluslararası Havayolları Şirketlerinin Covid-19 Salgını Sürecinde Instagram'da Marka... 331

Wang (2014) ise, şirketlerin krizleri firsata dönüştürmek için sosyal medyayı nasıl kullandığını ve tüketicilerin bu marka yönetimi stratejisine nasıl tepki verdiklerini incelemiştir. Çalışmada, iki marka arasında yaşanan anlaşmazlık ve yargı süreci sonrasında, bir markanın mahkeme kararını sosyal medyada protesto etmesinin; oluşan krizin olumsuz etkilerini azaltarak; halkta sempati ve destek oluşturduğu tespit edilmiştir. Han vd. (2018) ise, kriz iletişiminde marka kişiliğinin rolünü, sosyal medya platformlarını temel alarak analiz etmiştir. Bu çalışmada, kriz öncesi ve sonrası dönemde Facebook ve Netflix'in marka kişiliklerini yansitarak hedef kitle ile iletişim kurmaya devam ettikleri tespit edilmiştir. Ayrıca, araştırmada kriz dönemine özel olarak iletişim ağlarını güçlendiren marka stratejilerine; sosyal medya paylaşımlarında daha fazla yer verdikleri sonucuna ulaşılmıștır. İncelenen markaların, krize tepki verme biçimlerinin ise, kısmen pasif olduğu; fakat Netflix ve Facebook'un "şeffaflık" gibi kriz öncesi dönemde uyguladıkları temel marka iletişim stratejilerini sürdürdükleri görülmüştür. Benoit (2018), United Airlines'ın yolcusunu uçaktan sürükleyerek çıkarması ve görüntülerin sosyal medyaya düşmesi sonucu ortaya çıkan krizi, imaj restorasyon teorisi bağlamında ele almıştır. Çalışma sonucunda, düzeltici eylemlerin, önemli bir kriz iletişimi stratejisi olabileceğini; ancak sosyal medyanın bir krizi anlık ve eleştirel bir biçime getirme ihtimali olduğu için, krizle karşı karşıya kalan firmaların tepki vermek için zamanı doğru kullanmasının önemi ortaya konmuştur. Sosyal medya kaynaklı krizleri imaj restorasyon yaklaşımı bağlamında ele alan bir diğer araştırma da, Duğan (2018) tarafından gerçekleştirilmiştir. Çalışmasında, araştırmacı sosyal medya krizlerinde, kurumların büyük bir kısmının özür dileyerek tepki azaltma, krize neden olan kişiyi işletmeden uzaklaştırarak kesme, krize neden olan mesaj1 sosyal medyadan kaldırarak silme ve krizi bir daha yaşamamak için düzenleyici eylem stratejisi kullandıklarını saptamıştır.

Sosyal medya, halkın krizler hakkında bilgi edinme biçimlerini, müdahale çabalarına yönelik beklentilerini değiştirmekte ve kriz durumlarının görünürlüğünü artırmaktadır (Austin vd., 2012; Spence vd., 2006; Westerman vd., 2014). Alexander (2013), acil durumlarda, farkl1 sosyal medya platformlarının yedi farklı şekilde kullanıldığını ifade etmektedir: Kitlenin tartışmalarına kulak verme, durumları izleme, acil durum müdahalesini ve yönetimini genişletme, kalabalık kaynak bulma/işbirlikçi gelişim, sosyal uyum yaratma, sorunlara çözüm bulma (hayırsever bağış dahil) ve araştırmayı geliştirme. Örneğin Eylül 2010 'da, Colorado tarihinin en kötü orman yangını olan Boulder Fourmile yangınında, yaklaşık 6385 dönüm arazi yanmış ve 200'den fazla yapı zarar görmüştür. Bu kriz sırasında topluluk, krizle ilgili bilgileri yaymak için sosyal medyayı aktif biçimde kullanmıştır. Yangın ilk olarak 7 Eylül 2010'da sabah saatlerinde rapor edilmiştir. Ardından bir kullanıc \#boulderfire hashtagini kullanarak itfaiye raporlarını Twitter'da paylaşmaya başlamıştır (Orange Insights, 2010). Öğle saatlerine gelindiğinde, başka bir kullanıcı, yangın/tahliye alanlarını, fotoğraflarını ve acil müdahale çalışmalarını belirlemek için bir Google haritası oluşturmuş ve 1.8 milyon görüntüleme elde etmiştir (Stephens, 2010). Yoo vd. (2016) ise, kriz dönemlerinde bilginin sosyal medya platformları aracılığı ile etkili yayılma düzeyini analiz etmiştir. Bu çalışmada, araştırmacı, Sandy kasırgası boyunca insani yardım kuruluşlarının Twitter paylaşımlarının; diğer kaynaklara kıyasla, daha hızlı yayıldığını tespit etmiştir. Bu iki örnek, sosyal medya ağlarının, acil bilgi yayılımı gerektiren insani krizler sırasında bilgi aktarımında önem taşıdığını açıkça ortaya koymaktadır.

Kriz iletişimi sürecinde sosyal medya kullanımı işletmeler açısından önem taşımakla birlikte, kurumların stratejilerine uygun hareket etmeye ve krizin etkisiyle yanlış anlaşılmaya neden olabilecek içerik paylaşımlarından kaçınmaya özen göstermesi gerekmektedir (Aslan, 2016: 517). Sosyal medya, halkın duygu ve düşüncelerini dile getirebileceği bir ortam sağladığ içim, çevrimiçi alanda oluşan problemler; çevrim dışı dünyada yaşanan sorunlara kıyasla daha ön görülemez olabilir. Bu nedenle, kriz yöneticileri sosyal medyada oluşup; yayılan sorunları izleme ve çözme konusunda yeni zorluklarla karşılaşabilmektedir (Coombs, 2008). Dolayısıyla kurumlar, sosyal medyada gerçekleştirdikleri iletişim faaliyetlerini hem normal, hem de kriz dönemlerinde dikkatli 
planlamalıdır. Ancak, Covid-19 salgını gibi çok sayıda işletmeyi ve sektörü dışsal bir krize sürükleyen uzun dönemli sorunlarda, maliyet kısıtlamaları olmadan; etkileşimli ve hızlı bir biçimde stratejik marka iletişim faaliyetlerinin sürdürülebilmesi için sosyal medya platformlarının önemi artmaktadır.

\section{Marka İletişimi ve Sosyal Medya}

Günümüzde, markalar açısından hedef kitle ile ilişki kurmak ve o ilişkiyi sürdürmenin önemi giderek artmaktadır. Çevrimiçi mecralar ise, marka ve hedef kitle arasındaki ilişkiyi kurmak ve sürdürmenin en önemli araçları arasında yer almaktadır (Ki ve Hon, 2006; Cho ve Huh, 2010). Sosyal ağların geniş bir kitleye seslenmesi ve seslenilen kitlenin spesifik özelliklerinin bilinmesi; bu platformları, marka iletişimi yönünden cazip k1lmaktadır. Sosyal medya platformlarının, marka iletişimi açısından işletmeler sağladığı avantajlar, niş ya da geniş kitlelere kolay erişim, etkileşim oluşturarak hedef kitleyi tanıma ve gereksinimlerini belirleme olarak sıralanmaktadır (BabürTosun, 2010: 389-390). Çok sayıda sosyal medya platformunun etkileşimli yapısı, çevrimiçi tartışmalara olanak sağladığ 1 için; marka, kendisi ve rakipleri hakkında hedef kitlenin düşünce ve duygularını öğrenme olanağına kavuşmuştur. Bu bilgiler markalar için yeni firsatlar yaratırken, markaya ilgi duyabilecek farklı topluluklara kolayca erişilmesini de sağlamaktadır (Davis, 2011: 391). Ayrıca, sosyal medya platformları markaların iletişim sürecinde, geleneksel medyada olduğu gibi eşik bekçilerine takılma engeli yaratmamakta, mesajların doğrudan hedef kitleye ulaşmasını sağlamakta ve hedef kitleden geribildirim alma olanağı da yaratmaktadır (Özgen ve Elmasoğlu, 2016: 199). Bu nedenlere bağlı olarak, günümüzde birçok marka, sosyal medyaya yaptıkları yatırım oranını arttırmıştır (Öztürk, 2015: 123). Sosyal medyada gerçekleştirilen marka iletişimi faaliyetleri aracılığıyla işletmeler müşteri ilişkilerinin yönetimi, ürün ve hizmetlerin tanıtımı, tüketicilerin eğitimi ve bilgilendirilmesi, hedef kitlenin satın alma davranışına yönlendirilmesi gibi çok sayıda farklı uygulama gerçekleştirilebilmektedir (Mangold ve Faulds, 2009:361-364). Markaların sosyal medyada anlamlı, organik ve etkileşimli içerikler oluşturmasının en önemli araçları arasında yer alan sosyal medya sayfaları, işletmelerin marka iletişimi ve tüketici etkileşimi amacıyla kurdukları platformlar olarak tanımlanmaktadır. Sosyal medyada paylaşılan marka iletileri ise, işletmelerin herhangi bir ücret ödemeden, kolay, hızlı ve sıklıkla üretebildiği ve takipçilerin/potansiyel müşterilerin günlük olarak bir marka ile ilgili bildirim almasına izin veren paylaşımlar olarak tanımlanmaktadır. Marka sayfaları ve yapılan paylaşımlar, takipçi kitlesinin markanın düzenli olarak gerçekleştirdiği iletişimi takip etmesine imkan tanırken; beğeni, yorum ve paylaşım olanağı sağlayarak; tüketicilerin birbirleriyle etkileşime geçmesini de olanaklı hale getirmektedir. (Lipsman vd., 2012, Tafesse, 2015:940, Tafesse, 2016:433-433, Zaglia, 2013:221222; Tafesse ve Wien:2017:4-5).

Günümüzde, markalar sürdürülebilir ilişkiler kurmak için sosyal medya platformlarına özel stratejiler geliştirmektedir. Bu stratejiler, pozitiflik (ilişkiyi hedef kitleler için daha eğlenceli hale getirme), açıklık (kuruluşun doğası ve ne yaptığı hakkında bilgi sağlama), ağ oluşturma (ağlar veya koalisyonlar oluşturma/ aynı gruplarla kamuoyu oluşturma), görevleri paylaşma (projeleri paylaşma ya da ortak çıkarları çözme) ve güvence (hedef kitleyi meşru olduklarına inandırma) olarak sıralanmaktadır (Ki ve Hon, 2006; Cho ve Huh, 2010). İşletmelerin sosyal medya sayfalarında paylaşılan içeriklerinin, marka iletişimi stratejileri ve marka kişiliğinin yansıtılması açısından kullanımına dair; alan yazında çok sayıda araştırma gerçekleştirilmiştir. Bu çalışmalara; de Vries vd. (2012)'nin 11 uluslararası markanın Facebook paylaşımlarını etkileşim, bilgilendirme, eğlence, canlılık değişkenleri üzerinden analiz ettiği çalışma, Taecharungroj (2016)'ın Starbucks'ın Twitter kullanımını bilgi paylaşımı, duygusal içerik paylaşımı ve eyleme yönlendirme amaçlı içerik paylaşımı kategorilerini temel alarak irdelediği inceleme örnek olarak verilebilir. Ayrıca, Vassollo vd. (2018); Instagram'da 15 hazır yemek ve abur cubur gida markasının pazarlama stratejilerini inceledikleri araştırmada, markaların paylaşımlarını bilgilendirici ve imaj odaklı olarak iki kategori 
Uluslararası Havayolları Şirketlerinin Covid-19 Salgını Sürecinde Instagram'da Marka... 333

üzerinden analiz etmiştir. Çalışmanın araştırma modeline de temel oluşturan bu analizde, alt marka iletişimi kategorileri olarak ünlü kullanımı, sponsorluk, etkileşim oluşturma gibi farklı stratejiler de değerlendirilmiş̧ir. $\mathrm{Bu}$ araştırmaya temel oluşturan bir diğer çalışmada ise, Tafesse ve Wien (2017), Interbrand Best Global Brand araştırmasına göre başarılı bulunan markaların Facebook sayfalarını analiz etmiştir. $\mathrm{Bu}$ çalışmada, araştırmacılar markaları paylaşımlarında duygusal, fonksiyonel, eğitici içerik kullanımı, etkinlik duyurumu, müşteri ilişkileri, amaca yönelik pazarlama faaliyetleri, promosyon duyurumu gibi farklı stratejilere yer verme düzeyleri üzerinden değerlendirmiştir. Wattanacharoensil ve Schuckert (2015) ise, havalimanlarının Facebook paylaşımlarında yer verdiği marka iletişim stratejilerini hava limanı atmosferi, yer tanıtımı, bilgi güncellemeleri, araştırma ve anketler, etkinlik duyurumu gibi farklı kategoriler üzerinden analiz etmiştir. Özgen ve Elmasoğlu (2016), Türkiye'deki havayolu şirketlerinin marka iletişimi amaciyla sosyal medyayı kullanım biçimini Twitter üzerinden inceledikleri araştırmalarında, üç hava yolu şirketinin de daha çok satışı teşvik edici iletiler paylaştıklarını, THY'nin iletilerinde düz metinlere daha yoğun yer vermesine karşın; Pegasus Airlines ve Anadolu Jet'in iletilerinde "url" kullanılarak bağlantılılık oluşturmayı amaçladığını tespit etmiştir. Bu araştırmalar, sosyal medya platformlarının farkl1 sektörlerde faaliyet gösteren firmalar tarafindan; stratejik marka iletişimi faaliyetleri amacıyla etkin olarak kullanıldığını göstermektedir.

Sosyal medya içerikleri farklı marka stratejilerinin uygulanması kadar; marka kişilik boyutlarının yansıtılması için de olanak sağlamaktadır. Aaker (1997)'e göre, marka kişiliği bir markaya atfedilen bir dizi insani vasıf ya da özellik olarak tanımlanmaktadır. Marka kişiliği kavramı, bir markanın rakiplerinden, insanlara özgü demografik, sosyal, kültürel ve bilişsel özellikler çerçevesinde farklılaşmasını sağlayan niteliklerin tamamı olarak tanımlanabilmektedir. İnsana özgü özelliklerin marka aktarımıyla marka kişiliği, işletmelere rakiplerden farklılaşma ve iletişim çalışmalarına yön verme açısından da önemi katkılar sağlamaktadır. Araştırmalar, tüketicilerin ürün/markanın fiziksel özellikleri ile birlikte, markaların kişilikleri ile kendi kişilikleri arasında oluşan uyumu dikkate aldıklarını ortaya koymaktadır (Babür-Tosun, 2010: 68; Uztuğ, 2003: 41-42). Bu çalışmaya da temel oluşturan Aaker (1997)'nın marka kişiliği ölçeği, beş boyuttan oluşmaktadır. Bu boyutlar, samimiyet (dürüst, neşeli, samimi vb.), heyecan (cesur, yaratıcı, modern vb.), yetkinlik (güvenilir, emniyetli, başarılı vb.), seçkinlik (üst sınıf, büyüleyici) ve sağlamlık (haşin, sert, dayanıklı) olarak sıralanmaktadır (Aaker, 1997: 354). Aaker (1997)'nin ölçeği temel alınarak havayolu şirketlerinin marka kişilik boyutlarını ölçme amacıyla gerçekleştirilen araştırmalara, Ramaseshan ve Tsao (2007)'nun Singapur; Uca Özer ve Kayaalp Ersoy (2012)'nin Türkiye; Cervera-Taulet vd. (2013)'in İspanya özelinde yaptığı çalışmalar verilebilir. Bu çalışmada, araştırma modelinin belirlenmesinde Cervera-Taulat vd. (2013)'in reklamların hava yolu şirketlerin marka kișiliği üzerindeki etkisini belirlemeye yönelik araştırmalarında yer alan, "heyecan", "samimiyet", "yetkinlik" ve "seçkinlik" boyutları temel alınmıştır. Hava yolu şirketlerinin marka kişiliklerini belirlemeye yönelik gerçekleştirilen diğer çalışmalara ise, Kotsi ve Valek (2018)'in, Birleşik Arap Emirlikleri menşeli iki havayolu şirketi olan Etihad Airways ve Emirates'in reklamlarında ünlü kullanımının marka kişiliği üzerindeki etkisini inceledikleri araştırma verilebilir. Araştırma sonucunda, iki hava yolu şirketi arasında beş marka kişiliği boyutundan üçünün (samimiyet, heyecan, yetkinlik) reklamlar aracılığı ile farklı bir biçimde sunulduğu tespit edilmiştir. Park vd. (2004) ise, Kore uluslararası hava yolu kullanıcıları üzerine gerçekleştirdikleri bir araştırmada, hizmet değeri, yolcu memnuniyeti ve imajın karar alma sürecinde doğrudan bir etkisi olduğunu tespit etmiştir. Ayrıca, (Murphy vd. 2007)'nin belirttiğgi üzere, destinasyonları ayırt etmek için kullanılan marka kişilik özellikleri bölgelere göre farklılaştı̆̆ için, uçuş güzergahlarının kişilik boyutları farklı iletişim stratejileri aracılığıyla markaya da atfedilebilmektedir. Han vd. (2018)'in vurguladığ 1 üzere, sosyal medya hem normal, hem kriz dönemlerinde marka kişiliği temelli iletişim faaliyetleri için bir alan oluşturmakta ve markalar sosyal ağlar aracıllğıyla kişiliklerini inşa edebilmektedir. Ancak, üzerinde önemle 
durulması gereken bir husus, kriz dönemlerinde tüketici beklenti ve ihtiyaçlarının değişimine bağlı olarak; uygulanan marka iletişim stratejileri ve yansıtılan marka kişilik boyutlarının da farklılaşması gerektiğidir.

IPSOS (2020)'nin Covid-19 pandemisi sürecinde ABD merkezli olarak yaptığı bir araştırmada, katılımcıların \%74'ü hastalıkla mücadele sürecine destek veren işletmelerin marka iletişimi faaliyetleri ile ilgili bilgi sahibi olmayı talep ettiklerini; \%72'si ise bu süreçte markaların topluma karşı sorumlu davranması gerektiğini belirtmiştir. Ayrıca, araştırma sonucunda Covid-19 dönemi boyunca; markaların farklı mecralarda gerçekleştirdikleri iletişim çalışmalarının değişen oranlarda katılımcılarda, güvenli, güçlü, mutlu/eğlenceli, pozitif çağrışımlar uyandırdığı tespit edilmiştir. $\mathrm{Bu}$ süreçte, markaların üstlendiği roller ise; güvenilir ve ilgili/yardımcı olarak belirtilmiştir (Sheridan vd., 2020:6)

\section{Covid-19 Salgını Döneminde, Uluslararası Hava Yolu Şirketlerinin Instagram Paylaşımlarının Analizi}

Bu çalışmada, dünyada ve ülkemizde etkili olan Covid-19 salgını döneminde, uluslararası havayolu şirketlerinin resmi Instagram sayfalarında yer alan içerikler, marka iletişim stratejilerinin değişimi, marka kişilik boyutlarının/çağrışımlarının sunumu, biçimsel yapı ve etkileşim düzeyi değişkenleri temele alınarak nicel ve nitel içerik analizi yöntemi ile 05.01.2020-31.06.2020 tarihleri arasında analiz edilmiştir. Böylece, ilgili havayolu şirketlerinin Covid-19 döneminde değişen marka iletişim stratejileri ve marka kişilik boyutlarının sunumu kriz iletişimi yaklaşımı çerçevesinde; karşılaştırmalı olarak ortaya konulmuştur. Araştırma soruları ise, şu şekilde belirlenmiştir.

1. İncelenen hava yolu şirketlerinin Instagram paylaşımlarında kriz öncesi ve kriz dönemlerinde kullandıkları marka iletişim stratejileri nasıl farklılaşmıştır?

2. İncelenen hava yolu şirketlerinin Instagram paylaşımlarında Covid-19 salgınına özel uygulanan marka iletişim stratejilerinin benzerlik ve farklılıkları nelerdir?

3. İncelenen hava yolu şirketlerinin Instagram paylaşımlarında kriz öncesi ve kriz dönemlerinde yansıttıkları temel marka kişilik boyutları nasıl farklılaşmıştır?

4. İncelenen hava yolu şirketlerinin Instagram paylaşımlarında Covid-19 salgınına özel kullanılan marka çağnışımlarının benzerlik ve farklılıkları nelerdir?

5. İncelenen hava yolu şirketlerinin Instagram sayfalarında yer alan iletilerin kriz öncesi ve kriz döneminde etkileşim düzeyi nasıl bir farklılaşmıştır?

\section{Araştırmanın Amacı, Örneklemi ve Sınırılıkları}

Çalışmanın amacı, Covid-19 salgınında kriz öncesi ve kriz boyunca; Türk Hava Yolları (THY), Amerikan Airlines (AA) ve British Airways (BA) hava yolu firmalarının Instagram hesaplarında yer alan iletilerin, genel ve Covid-19 dönemine özel uyguladıkları marka iletişimi stratejileri, biçimsel yapı, etkileşim düzeyi, marka kişiliği boyutları ve Covid-19'a özel marka çağrışımları temel alınarak; karşılaştırmalı olarak incelenmesidir. Böylece, dünya çapında havayolu ulaşımını sınırlayarak/durdurarak bir kriz oluşturan salgının; farklı ülkelerde faaliyet gösteren hava yolu şirketleri tarafından sosyal medyada nasıl yönetildiğine yönelik bir çerçeve oluşturulacaktır.

Çalışmanın evrenini, dünyada havayolu sektöründe faaliyet gösteren ve resmi Instagram hesapları bulunan tüm şirketler oluşturmaktadır. Çalışmanın örneklemi ise, amaçlı örneklem yöntemi ile belirlenmiştir. Amaçlı örneklem yönteminde, örnekleme dahil edilen kişi veya nesnelerin çalışma amaçlarına uygun yanıtlar verebilecek özellikte olması önem taşımaktadır (Aziz, 2008: 55). Örneklemin havayolu şirketleri ile sınırlandırılmasının temel nedenleri, alan yazında tartışıldığı üzere, salgın döneminde uluslararası hava trafiğinin yavaşlaması, hava yolu şirketlerinin ertelenen ve iptal edilen uçuşlar nedeniyle, yüksek bir ekonomik kayıpla karşı karşıya 
Uluslararası Havayolları Şirketlerinin Covid-19 Salgını Sürecinde Instagram'da Marka... 335

kalmasıdır. Örneklem içerisine Türk Hava Yolları, American Airlines ve British Airways havayolu şirketlerinin resmi Instagram hesapları dahil edilmiştir. Bu seçimin temel nedeni; ilk vaka sayılarının ülkelerde görülme dönemlerinin benzerliği; inceleme döneminde hastalık kaynaklı aktif vaka sayısı ve ölüm oranı en yüksek olan ilk iki ülkenin Amerika Birleşik Devletleri ve İngiltere olmasının havacılık sektörünün etkilenme potansiyelinin yüksekliğidir. Ayrıca, OAG Schedule Analyser (2019) verilerine göre; bu havayolu şirketlerinin kuruldukları ülkede, farklı ülkelere uçuş gerçekleştiren (Türk Hava Yolları:121; Amerikan Airlines:62; British Airways:82) ve en fazla hava limanına uçuş yapan (Amerikan Airlines:361; Türk Hava Yolları: 279; British Airways: 224) ulusal nitelikte hava yolu şirketleri olmaları da; örneklem seçiminde belirleyici olmuştur.

Araştırma nesnesi olarak; örneklem dahilinde incelenen havayolu şirketlerinin resmi Instagram hesapları alınmıştır. Çalışmada bir sosyal medya platformu olarak Instagram'ın tercih edilmesinin temel nedenleri ise; Çetinkaya ve Özdemir (2012:590); Ginsberg (2015:80); Goor (2012: 31)'un belirttiği üzere; tüm sosyal ağlarda görsel içeriklerin metinsel içeriklere göre daha fazla ilgi çekmesinin ve paylaşım oranının yüksekliğine bağlı olarak; görsel ağırlıklı bir sosyal medya platformu olarak Instagram'ın markalara değer ve kişiliklerini yansıtma imkanı sağlaması, etkileşim oluşturma potansiyeli ve mecranın farklı marka iletişim stratejilerinin uygulanmasına olanak tanımasıdır. We are Social (2020)'ın "April Global StatsReport” başlıklı raporunda ise, Covid-19 salgını döneminde, tüm dünyada İnternet kullanıcılarının \%23'ünün sosyal medyada daha fazla zaman geçirdiği sonucuna ulaşılmıştır. Ayrıca, bu dönemde toplam sosyal medya kullanım oranı 304 milyon (\%8.7) oranında artmıştır. Dünya çapında, nisan ayında aktif Instagram kullanıcı sayısı, 1 milyar kişinin üzerindedir. Salgın döneminde, işletme/marka hesaplarının toplam etkileşim düzeyi \%1.52 oranında; görsel içeriklerin etkileşim düzeyi \%1.64 oranında; videoların etkileşim düzeyi \%1.52 oranında artış göstermiştir. Ayrıca, marka/işletme bağlantılı hesapların aylık ortalama takipçi artış1 \%2.79 düzeyinde gerçekleşmiş̧ir. Raporda 18-65 yaş arası sosyal medya kullanıcılarının \%49'unun aktif olarak mecrayı kullandığ 1 ve 25-34 (\%18) ve 18-24 (\%16) yaş aralığına sahip kullanıcıların; Instagram'ı en fazla kullanan grubu oluşturduğu sonucuna ulaşılmıştır. Statista (2020)'nin Nisan ayı istatistiklerine göre ise, dünyada mecranın en çok kullanıldığ 1 ülkeler arasında 120 milyonu aşkın kullanıcı ile birinci sırada Amerika Birleşik Devletleri gelmektedir. Türkiye'de 39 milyon, İngiltere'de ise 25 milyonu aşkın aktif Instagram kullanıcısı bulunmaktadır. Bu etmenler, uluslararası hava yolu şirketlerinin Instagram hesaplarında yer alan iletilerin incelenmesinde belirleyici olmuştur. Araştırmanın zaman aralığı ise, Dünya Sağlık Örgütü (2020)'nün (World Health Organization/WHO) ilk olarak Çin'de ortaya çıkan yeni virüs salgını ile ilgili olarak küresel medyaya açıklama yaptığ 5 Ocak 2020 ile ülkelerin kademeli normalleşme sürecine girdiği 1 Haziran 2020 tarihi ile sınırlandırılmıştır. İncelenen iletilerin, araştırma sonrası dönemde değişim, silinme ve etkileşim düzeylerinde değişme olasılığ 1 da bulunmaktadir.

\section{Araştırma Metodolojisi}

Çalışmada, uluslararası hava yolu şirketlerinin Instagram hesaplarında yer alan iletilere yönelik nitel ve nicel (etkileşim düzeyi) içerik analizi gerçekleştirilmiştir. İçerik analizi, yazılı içeriği objektif, sistemli ve nicel olarak belirlemeye imkân tanıyan bir yöntemdir (Berelson, 1952:6). İçerik analizi yönteminde nesnellik, araştırma boyunca tanımlanan başlıkların farklı araştırmacılar tarafından analizi ile benzer sonuçlara erişim amacı taşımaktadır. Yöntemin sistematikliği, çözümlenmesi hedeflenen görsel ve metinlerin belirli kurallar doğrultusunda analizi olarak ifade edilmektedir. Niceliksellik ise, metin ve görselllerin analizi sonucunda sayısal veriler ve istatistiki sonuçlara ulaşma olarak tanımlanmaktadır (Akdenizli, 2012:135-136). İletişim bilimi disiplini içerisinde, kitle iletişim araçlarında yer alan mesajları inceleme amacıyla sıklıkla kullanılan yöntem, günümüzde etkileşimli yeni medya içeriklerinin analizi amacıyla da kullanılmaktadır (Baxter ve Babbie, 2004: 314; Jensen, 2011: 52). İçerik analizi yönteminde, analizde yer alan kodlar/kategoriler incelenen konuya göre oluşturulabilmektedir. Bu doğrultuda, 
çalışmada Vassollo vd. (2018:3)'in Instagram'da marka iletişim stratejileri sınıflandırması, Tafesse ve Wien (2017:10)'in sosyal medyada marka içerikleri araştırması, Wattanacharoensil ve Schuckert (2015:661-671)'in havaalanlarının sosyal medyada etkileşim oluşturma tipolojisi, Han, Hi Sung ve Hoo Kim (2017:817-818)'in kriz dönemlerinde markaların sosyal medyada iletişim stratejileri kodlaması, Aaker (1997:354)'ın marka kişiliği boyutları sınıflandırması, Cervera-Taulet vd. (2013:449)'in hava yolu şirketlerinin marka kişiliği boyutları tipolojisi, Sheridan vd. (2020:6)'nin Covid-19'a sürecinde markaların tüketiciler üzerinde oluşturduğu duygular (marka çağrışımları) araştırması ve salgın sürecinde sosyal medyada aktarılan yeni marka kişiliği boyutları temel alınarak; aşağıda yer alan araştırma modeli dizayn edilmiştir.

Tablo 1: Araştırma Modeli

\begin{tabular}{|c|c|}
\hline Marka İletişim Stratejileri & Açıklama/Kodlama Kriterleri \\
\hline \multicolumn{2}{|c|}{ Ana Kategori } \\
\hline Bilgilendirme & İletilerde, hizmet ve özellikleri ile ilgili olarak bilgi verme \\
\hline İmaj Oluşturma & $\begin{array}{l}\text { İletilerde, marka imajı oluşumu amacıyla duygusal ya da } \\
\text { hedef kitlenin yaşam tarzını temel alan içerik kullanımı }\end{array}$ \\
\hline \multicolumn{2}{|c|}{ Alt Kategori } \\
\hline Sosyal Sorumluluk Faaliyetleri Duyurumu & $\begin{array}{l}\text { İletilerde bir sosyal sorumluluk faaliyetine destek } \\
\text { verilmesi/bağış/STÖ işbirlikleri/ yardım kampanyaları } \\
\text { konulu içerik kullanımı }\end{array}$ \\
\hline Ünlü kullanımı & İletilerde ünlü/tanınmış kişi kullanımı \\
\hline Hizmeti temsil eden araç kullanımı (Uçak) & $\begin{array}{l}\text { İletilerde, ana hizmet alanı olan ulaşımla bağlantılı uçak } \\
\text { kullanımı }\end{array}$ \\
\hline Personel Kullanımı & $\begin{array}{l}\text { İletilerde, çalışan/yönetici kullanımı ve açıklamaları (sorun } \\
\text { çözme kapasiteleri, yaşam tarzları, yönetim felsefeleri vb.) }\end{array}$ \\
\hline Yer (Destinasyon) Kullanımı & $\begin{array}{l}\text { İletilerde, uçuş güzergahında bulunan bir ülkenin/ şehrin/ } \\
\text { bölgenin coğrafi, kültürel, sosyal çekiciliklerinin tanıtımı }\end{array}$ \\
\hline Tüketici Kullanımı & $\begin{array}{l}\text { İletilerde tüketicinin deneyimleri, tercihleri ilişkileri üzerine } \\
\text { odaklanılması, müşterilerin aile/arkadaşlık ilişkileri, } \\
\text { gelecek planları, kişisel hikayelerine yoğunlaşılması/ } \\
\text { tüketici yorumları-müşteri ilişkileri sürecine yer verilmesi }\end{array}$ \\
\hline Promosyon Duyurumu & $\begin{array}{l}\text { İletilerde, tüketicileri satın alma davranışına yönlendirmek } \\
\text { için uygun fiyat, kolay erişim, promosyon taktiksel satış } \\
\text { bileşenlerine yer verilmesi }\end{array}$ \\
\hline Etkinlik Duyurumu/Kutlama & $\begin{array}{l}\text { İletilerde, kültürel etkinler, bayramlar, festivaller, yı1 } \\
\text { dönümleri gibi içeriklere yer verilmesi/kutlama mesajları }\end{array}$ \\
\hline $\begin{array}{l}\text { Etkileşim Oluşturma Amaçlı İçerik } \\
\text { Paylaşımı }\end{array}$ & $\begin{array}{l}\text { İletilerde, tüketici ile çift yönlü iletişimi/etkileşimi } \\
\text { geliştirmeyi amaçlayan mesaj kullanımı (yarışma } \\
\text { duyuruları, düşüncelerinizi bizimle paylaşım ifadesine yer } \\
\text { verilmesi vb.) }\end{array}$ \\
\hline
\end{tabular}

Kriz Dönemlerine Özel Marka Stratejileri

Olumluluk (Pozitiflik) Bir markanın/kurumunun potansiyel hedef kitlesi ile ilişkisini neşeli/eğlenceli/ olumlu bir hale getirme çalışmaları (Covid-19 döneminde topluma olumlu mesajlar verilmesi) 
Uluslararası Havayolları Şirketlerinin Covid-19 Salgını Sürecinde Instagram'da Marka... 337

Şeffaflık ve Sorumluluk Alma

Destek Verme

Bağ kurma/ Ağlar Oluş̧urma
Markanın yaşanan krizle ilgili olarak hedef kitlesini şeffaf bir biçimde bilgilendirme/ sorumluluklarını yerine getirmesi (Covid-19 döneminde, ertelenen uçuşlarla ilgili bilgilendirme/çözüm sunma)

Markanın kriz döneminde sosyal bir amaç içeren ileti paylaşımı (Covid 19 döneminde sağlık çalışanlarını alkışlama)

Markanın kriz mağdurlarına yardımcı olma amacıyla işbirlikleri gerçekleştirdiği ileti paylaşımı (Covid-19 döneminde ihtiyaç sahibi kişi ve ülkelere tıbbi malzeme götürme/ bağış yapma vb.)

\begin{tabular}{|c|c|}
\hline \multicolumn{2}{|c|}{ Marka Kişiliği Boyutları } \\
\hline Samimiyet & $\begin{array}{l}\text { Dürüstlük, Cana yakınlık/Arkadaş canlılığı, Aile odaklılık, } \\
\text { Samimiyet, Gerçekçilik, Neşelilik, Duygusallık, Dürüstlük, } \\
\text { Erdemlilik (Covid 19'a özel: Vatanseverlik, Fedakarlık, } \\
\text { Toplum, Topluluk Yararını Düşünme)/ Nostaljik } \\
\text { Geleneksellik, Sadelik }\end{array}$ \\
\hline Heyecan & $\begin{array}{l}\text { Cesaret, Canlılık, Yaratıcılık, Çağdaşlık/Modernlik, } \\
\text { Heyecanlılık/Keşif, Karizmatiklik, Gençlik, } \\
\text { Eşssizlik/Biriciklik, Bağımsızlık/Bireysellik }\end{array}$ \\
\hline Yetkinlik & $\begin{array}{l}\text { Güvenilirlik, Sorumluluk, Konfor, Zeka, Başarılılık, } \\
\text { Çalışkanlık, Emniyetlilik, Teknik, Kurumsal, Lider, } \\
\text { Kendinden Emin, Temizlik }\end{array}$ \\
\hline Seçkinlik & Üst tabaka/Gösterişlilik, Çekicilik, Büyüleyicilik, \\
\hline
\end{tabular}

\begin{tabular}{|c|c|}
\hline \multicolumn{2}{|c|}{ Covid-19 Salgınına Özel Marka Çağrışımları } \\
\hline Eğlence & Mutluluk, Neşe \\
\hline Güç & Bilgili, Kendine güvenli, sorumluluklarını yerine getiren \\
\hline Güvenlik & $\begin{array}{l}\text { Güvende hissettiren, normal, güvence veren, panik } \\
\text { yaptırmayan, korkusuz }\end{array}$ \\
\hline Olumlu/Pozitif & Umutlu, iyi, rahatlamış, rahat, pozitif, sakin \\
\hline \multirow{2}{*}{\multicolumn{2}{|c|}{$\begin{array}{c}\text { Covid-19 Salgınına Özel Markanın Rolü } \quad \text { Güvenilir, ilgili/vardımcı } \\
\text { Biçimsel Yapı }\end{array}$}} \\
\hline & \\
\hline Görsel & $\begin{array}{l}\text { İletilerde görsel kullanımı (fotoğraf veya Adobe Photoshop, } \\
\text { Illustrator vb. programlarla oluşturulmuş içerik) }\end{array}$ \\
\hline Video & İletilerde video kullanımı \\
\hline Marka Kimliği Bileşenleri Kullanımı & İletilerde logo, slogan vb. kullanımı \\
\hline Bağlantılılık & $\begin{array}{l}\text { İletilerde web sayfalarına/ diğer sosyal medya } \\
\text { platformlarına bağlantılı link kullanımı }\end{array}$ \\
\hline \multicolumn{2}{|c|}{ Etkileşim } \\
\hline Beğeni/Görüntüleme Sayısı & $\begin{array}{l}\text { İletilerde sayfa takipçilerinin görsel beğeni/ video } \\
\text { görüntüleme sayısı }\end{array}$ \\
\hline Yorum Sayıs1 & İletilere yapılan yorum sayısı \\
\hline
\end{tabular}

Kaynak: Vassollo vd. (2018:3), Tafesse ve Wien (2017:10), Wattanacharoensil ve Schuckert (2015:661-671), Han, Hi Sung ve Hoo Kim (2017:817-818), Aaker (1997:354), Cervera-Taulet vd. (2013:449), Sheridan vd. (2020:6), 'den geliştirilmiştir.

Araştırmanın geçerliliği ve güvenilirliği ise, iki araştırmacının içeriklere yönelik kategorileri; iki kere kodlaması ile sağlanmaya çalışılmıştır. Bu bağlamda, araştırmanın güvenilirlik düzeyi, \%95.6 olarak hesaplanmıştır. 


\section{Bulgular}

Türk Hava Yolları, American Airlines ve British Airways hava yolu şirketlerinin, Covid-19 salgını sürecinde kriz öncesi ve kriz döneminde resmi Instagram paylaşımlarında yer verilen marka iletişim stratejileri, kriz (Covid-19) önemine özel uygulanan marka iletişimi stratejileri, marka kişiliği boyutları, Covid-19 dönemine özel marka çağrışımları; iletilerin biçimsel yapısı ve etkileşim düzeyleri ile ilgili veriler çalışmanın bu bölümünde detaylı bir biçimde analiz edilmiştir.

Grafik 1: İncelenen İletilerin Uluslararası Hava Yolu Şirketi Bağlamında Niceliksel Dağılımı

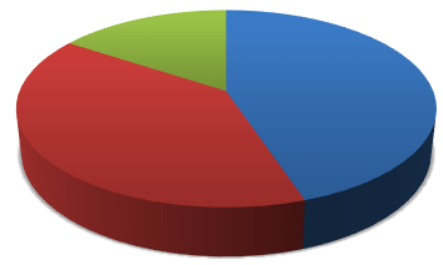

• Türk Hava Yollar1- \%44.9 (57 İleti)

- American Airlines- \%39.4 (50 İleti)

• British Airways- \%15.7 (20 İleti)

Grafikte görüldügü üzere, araştırma döneminde Instagram'da incelenen toplam 127 iletinin hava yolu şirketi bağlamında niceliksel dağılımında birinci sırada, \%44.9'luk oranla Türk Hava Yolları, ikinci sırada \%39.4'lük oranla American Airlines, son sırada ise \%15.7'lik oranla British Airways firmalarının geldiği görülmektedir. Bu bağlamda, stratejik marka iletişim faaliyetleri amacıyla; Türk Hava Yolları ve Amerikan Airlines firmalarının, mecrayı niceliksel olarak British Airways'e kıyasla daha etkin kullandığı sonucuna ulaşılmaktadır.

Tablo 2: Covid-19 Salgını Öncesi ve Salgın Döneminde Uluslararası Hava Yolu Şirketlerinin Instagram Sayfalarında Yer Alan İletilerin Niceliksel Dağılımı

\begin{tabular}{lllllll}
\hline Hava Yolu Şirketi & \multicolumn{2}{l}{ Türk Hava Yolları } & \multicolumn{2}{c}{ American } & Airlines & \multicolumn{2}{l}{ British Airways } \\
\hline Dönem & $\mathbf{n}$ & $\%$ & $\mathbf{n}$ & $\%$ & $\mathbf{n}$ & \% \\
$\begin{array}{l}\text { Covid-19 Salgını Öncesi } \\
\text { Dönem }\end{array}$ & 22 & $\% 38.6$ & 12 & $\% 24$ & 12 & $\% 60$ \\
$\begin{array}{l}\text { Covid 19 Salgını } \\
\text { Dönemi }\end{array}$ & 35 & $\% 61,4$ & 38 & $\% 76$ & 8 & $\% 40$ \\
\hline Toplam & 57 & $\% 100$ & 50 & $\% 100$ & 20 & $\% 100$ \\
\hline
\end{tabular}

Tabloda görüldüğü üzere, salgın öncesi dönemde Instagram sayfasında ileti paylaşım sayısı en yüksek olan hava yolu markası Türk Hava Yolları olarak tespit edilmiş olup; Covid-19 salgını döneminde ileti paylaşım sayısı en yüksek olan markanın American Airlines olduğu sonucuna ulaşılmıştır. Ayrıca, kriz döneminde THY'nin Instagram sayfasında içerik paylaşım sayısı yükselmiştir. Bu bağlamda, havayolu sektöründe uçuşların iptali, yolcu sayısının azalması gibi önemli etkilere yol açarak bir krize dönüşen Covid-19 salgını boyunca; THY ve American Airlines'ın potansiyel müşterileri/takipçileri ile etkileşimi sürekli tutmak amacıyla mecrayı etkin kullandıkları görülmektedir. Ancak; British Airways'in Instagram sayfasında içerik sayısının azalması; markanın unutulabilmesi, tüketici hassasiyetlerinin göz ardı edilmesi/alışılan deneyimin sağlanmaması gibi etkilere yol açabilecek temel bir eksikliktir. 
Tablo 3: Covid-19 Salgını Öncesi ve Salgın Döneminde Uluslararası Hava Yolu Şirketlerinin Instagram Sayfalarında Yer Alan İçeriklerin Marka İletişimi Stratejileri Bağlamında Analizi

\begin{tabular}{|c|c|c|c|c|c|c|c|c|c|c|c|c|}
\hline \multirow{3}{*}{$\begin{array}{l}\begin{array}{l}\text { Havayolu } \\
\text { Şirketi }\end{array} \\
\text { Dönem } \\
\text { Ana Kategori }\end{array}$} & \multicolumn{4}{|c|}{ Türk Hava Yolları } & \multicolumn{4}{|c|}{ American Airlines } & \multicolumn{4}{|c|}{ British Airways } \\
\hline & \multicolumn{2}{|l|}{$\begin{array}{l}\text { Kriz } \\
\text { Öncesi }\end{array}$} & \multicolumn{2}{|c|}{$\begin{array}{l}\text { Kriz } \\
\text { Dönemi }\end{array}$} & \multicolumn{2}{|c|}{$\begin{array}{l}\text { Kriz } \\
\text { Öncesi }\end{array}$} & \multicolumn{2}{|c|}{$\begin{array}{l}\text { Kriz } \\
\text { Dönemi }\end{array}$} & \multicolumn{2}{|c|}{$\begin{array}{l}\text { Kriz } \\
\text { Öncesi }\end{array}$} & \multicolumn{2}{|c|}{$\begin{array}{l}\text { Kriz } \\
\text { Dönem }\end{array}$} \\
\hline & $\mathbf{n}$ & $\%$ & $\mathbf{n}$ & $\%$ & $\mathbf{n}$ & $\%$ & $\mathbf{n}$ & $\%$ & $\mathbf{n}$ & $\%$ & $\mathbf{n}$ & $\%$ \\
\hline Bilgilendirme & 0 & 0 & 7 & 12.3 & 0 & 0 & 7 & 14 & 0 & 0 & 2 & 10 \\
\hline İmaj Oluşturma & 22 & 38.6 & 29 & 50.9 & 12 & 24 & 36 & 72 & 12 & 60 & 6 & 30 \\
\hline Alt Kategori & $\mathbf{n}$ & $\%$ & $\mathbf{n}$ & $\%$ & $\mathbf{n}$ & $\%$ & $\mathbf{n}$ & $\%$ & $\mathbf{n}$ & $\%$ & $\mathbf{n}$ & $\%$ \\
\hline $\begin{array}{l}\text { Sosyal } \\
\text { Sorumluluk } \\
\text { Faaliyetleri }\end{array}$ & 0 & 0 & 0 & 0 & 0 & 0 & 9 & 18 & 1 & 5 & 4 & 20 \\
\hline Ünlü kullanımı & 0 & 0 & 0 & 0 & 0 & 0 & 0 & 0 & 0 & 0 & 0 & 0 \\
\hline $\begin{array}{l}\text { Hizmeti temsil } \\
\text { eden araç } \\
\text { kullanımı }\end{array}$ & 7 & 12.3 & 18 & 31.6 & 0 & 0 & 11 & 22 & 1 & 5 & 2 & 10 \\
\hline $\begin{array}{l}\text { Personel } \\
\text { Kullanımı }\end{array}$ & 1 & 1.8 & 13 & 22.8 & 10 & 20 & 18 & 36 & 1 & 5 & 3 & 15 \\
\hline Yer Tanitımı & 12 & 21.1 & 1 & 1.8 & 1 & 2 & 1 & 2 & 11 & 55 & 0 & 0 \\
\hline $\begin{array}{l}\text { Tüketici } \\
\text { Kullanımı }\end{array}$ & 3 & 5.3 & 5 & 8.8 & 0 & 0 & 15 & 30 & 0 & 0 & 1 & 5 \\
\hline $\begin{array}{l}\text { Promosyon } \\
\text { Duyurumu }\end{array}$ & 0 & 0 & 0 & 0 & 1 & 2 & 0 & 0 & 1 & 5 & 0 & 0 \\
\hline $\begin{array}{l}\text { Etkinlik } \\
\text { Duyurumu }\end{array}$ & 2 & 3.5 & 10 & 17.5 & 2 & 4 & 7 & 14 & 3 & 15 & 1 & 5 \\
\hline $\begin{array}{l}\text { Etkileşim } \\
\text { Oluşturma }\end{array}$ & 2 & 3.5 & 12 & 21.1 & 1 & 2 & 3 & 6 & 3 & 15 & 0 & 0 \\
\hline
\end{tabular}

Marka iletişim stratejileri açısından incelenen hava yolu şirketlerinin Instagram kullanımları analiz edildiğinde temel benzerliğin; Covid-19 salgını öncesi dönemde üç hava yolu şirketinin de imaj oluşturma amaçlı içerik paylaşımı gerçekleştirmesi ve bilgilendirme stratejisi kullanmaması olduğu görülmektedir. Kriz döneminde ise; üç hava yolu firmasının da bilgilendirici içerik paylaşımında bulunduğu; ancak niceliksel olarak THY ve American Airlines'ın imaj oluşturma stratejisine iletilerinde daha yüksek oranda yer verildiği tespit edilmiştir. Bu sonuç, British Airways'in yaşanan havayolu krizi döneminde; Instagram'da temel marka iletişim stratejisini etkin bir biçimde sürdüremediğini ortaya koymaktadır. THY ve British Airways; Instagram'da bilgilendirici içerik paylaşımlarında, bilet değişimi/açığa alma hakları konulu iletilere yer vermiştir. American Airlines ise, salgın boyunca bazı bölgelere uçuşların devam etmesine bağlı olarak; uçak temizliği, yolcuların uyması gereken kurallar konulu ileti paylaşımında bulunmuştur. 
Ayrıca, THY'nin sayfasında uçuşların açılması öncesi dönemde; temizlik çalışmaları ve güvenlik önlemleri ile ilgili bilgilendirici içerikler de tespit edilmiştir.

Covid-19 salgını öncesinde, havayolu şirketlerinin alt marka iletişim stratejileri incelendiğinde; THY'nin \%21.1'lik oranla, British Airways'in \%55'lik oranla yer tanitımı; American Airlines'1n \%20'lik oranla personel kullanımına birinci sırada yer verdiği sonucuna ulaşılmıştır. THY ve British Airways, ortak marka iletişim stratejileri olan yer tanıtımında; uçuş güzergahlarında yer alan bölgelerin tarihi, doğal ve kültürel çekiciliklerini ön plana çıkarmıştır. Buna karşın, American Airlines uçuş personelinin profesyonelliği, yaşam öyküleri, takım ruhu gibi temalara Instagram iletilerinde daha fazla yer vermiştir. Ayrıca etkinlik duyurumu ve etkileşim oluşturma; firmaların sayfalarında ortak tespit edilen marka iletişim stratejileridir. Etkinlik duyurumunda, Amerikan Airlines ve British Airways sayfalarında 14 Şubat Sevgililer günü kutlamasına yer verirken; AA ayrıca \#blackhistorymonth (Afrika kökenli Amerikalıların Tarihi Ay1) ile ilgili de içerik paylaşımı gerçekleştirmiştir. THY ise; Instagram'da Superbowl Amerikan Futbolu Ligi'ne yapacağ 1 sponsorluğu ve etkinliği duyurmuştur. Etkileşim oluşturma amaçlı içeriklerde ise; havayolu şirketlerinin takipçilerine, en sevdikleri tatil rotası ya da gitmek istedikleri şehirler gibi sorular yönelttiği tespit edilmiştir. Covid-19 salgını öncesi dönemde, Instagram'da marka iletişim stratejileri açısından tespit edilen temel farklar ise; British Airways'in Tokyo Paralimpik Olimpiyatlarında İngiliz takımına sponsorluğunu duyurması (sosyal sorumluluk), tüketici kullanımına American Airlines'ın ve British Airways'in sayfalarında; promosyon duyurumlarına THY'nin sayfasında yer verilmemesi olarak sıralanabilir.

Covid-19 pandemisi sürecinde; incelenen iki havayolu şirketinin temel marka iletişim stratejileri olan yer tanıtımına; THY'nin sayfasında düşük düzeyde (\%1.8); British Airways'in sayfasında hiç verilmediği; American Airlines'ın Instagram sayfasında ise; kriz öncesi dönemdeki gibi personel kullanım stratejisine \%36'llk oranla birinci sırada yer verildiği sonucuna ulaşılmıştır. $\mathrm{Bu}$ dönemde, üç firmanın Instagram paylaşımlarında ortak kullanılan stratejiler ise; etkinlik duyurumu (sağlık çalışanlarının alkışlanması gibi etkinlikler), tüketici kullanımı (THY ve British Airways sayfalarında yurt dışında bulunan vatandaşların ülkeye getirilmesi; American Airlines sayfasında müşteri mesaj/görüntüleri paylaşımı); personel kullanımı (THY'nin sayfasında görevine devam eden ve uçakları temizleyen personelin görüntüleri, A.A'nın sayfasında çalışanların yazdığı notların ve yardım kampanyalarına verdikleri desteğin görüntüleri, British Airways'in sayfasında işine devam eden ve mücadele mesajı veren personel görüntüleri paylaşımı) ve hizmeti temsil eden bir araç olarak uçak görüntülerine yer verilmesi olarak sıralanabilir. Bu bulgular; üç hava yolu şirketinin de kriz öncesi döneme kıyasla, Covid-19 sürecinde farklı marka iletişim stratejilerini birlikte kullanarak, sürece uyum sağladıklarını ortaya koymaktadır.

Araştırma sonuçlarına bağlı olarak üzerinde önemle durulması gereken noktalardan biri ise; etkinlik duyurumunun ortak kullanılan bir strateji olmakla birlikte, ülkelerin tarihi ve kültürel özelliklerine bağlı olarak, farklılaşmasıdır. İnceleme döneminin, Türkiye'de Ramazan ayı/bayramı ve ulusal bayramlara denk gelmesi nedeniyle; THY çevrimiçi etkinlikler düzenleyerek, kutlama mesajları yayınlamıştır. Şirket, 23 Nisan Ulusal Egemenlik ve Çocuk Bayramı için gökyüzünde ay ve yıldız işareti çizmiş; 19 Mayıs Gençlik ve Spor Bayramı için ise; çok sayıda takipçiye Tarihi Yolculuk (Online Journey) uygulaması aracılığıyla çevrimiçi uçak bileti sağlayarak; sembolik bir İstanbul-Samsun uçuşu gerçekleştirmiştir. Amerikan Airlines'ın ve THY'nin Instagram sayfalarında; Dünya Pilotlar Günü, Dünya Kabin Memurları Günü, Anneler Günü gibi uluslararası düzeyde kutlanan özel günlere yönelik içeriklere yer verilmiştir. Ancak, British Airways'in sayfasında özel gün kutlamalarına yönelik bir ileti tespit edilmemesi; kriz dönemlerinde markatüketici-çalışan etkileşimi açısından temel bir eksikliği göstermektedir. Covid-19 döneminde incelenen hava yolu şirketlerinin marka iletişim stratejileri açısından temel farklılıklardan bir diğerinin ise; American Airlines ve British Airways sayfalarında \%18'lük ve \%20'lik oranlarla salgınla mücadele için gerçekleştirilen sosyal sorumluluk çalışmalarına yer verilirken, THY'nin Instagram sayfasında yer verilmemesi olduğu görülmektedir. İnceleme döneminde, AA sosyal 
Uluslararası Havayolları Şirketlerinin Covid-19 Salgını Sürecinde Instagram'da Marka... 341

sorumluluk faaliyetlerine, Instagram'da niceliksel olarak en fazla yer veren havayolu şirketi olmuştur. Covid-19 döneminde, havayolu şirketinin hesabında; firmanın kargo ile yardım ve tıbbi malzeme desteği sağladığı, çalışanlarının salgınla mücadele sürecinde yerel topluluklara destek verdiği, New York Şehri Hastaneler Birliği’ne bağlı sağlık çalışanlarına ücretsiz tatil etkinliği düzenlediği görsel ve videolar tespit edilmiştir. British Airways'in sayfasında ise, salgınla mücadele için personelin yerel STK'larla birlikte çalıştığı görüntülere ve yardım kampanyası için bağış duyurumlarına yer verilmiştir. THY'nin Instagram sayfasında ise, firmanın kargo filosunun toplumun ihtiyaçlarını gidermek için çalışmalarını sürdürdüğüne yönelik bir içerik tespit edilmekle birlikte; doğrudan sosyal sorumluluk çalışmalarını içeren bir içerik saptanmamıştır. Bu sonuç, toplumun kriz dönemlerinde markalardan sorunun çözümüne doğrudan dahil olmaları yönünde artan beklentileri doğrultusunda temel bir marka iletişim stratejisi eksikliği oluşturmaktadır. Salgın döneminde, etkileşim oluşturma amaçlı içerik kullanımı stratejisi ise, sadece THY'nin ve AA.'nın sayfalarında farklı oranlarda tespit edilmiştir. Pandemi döneminde, incelenen ülkelerde çok sayıda insanın evde karantinada kalması; İnternet ve sosyal medya kullanım alışkanlıklarını değiştirdiği için, THY'nin Ramazan Ayı boyunca paylaştığı yemek tarifi videolarında "Denediğiniz tarifleri bizi etiketleyerek paylaşmayı unutmayın!", 19 Mayıs Gençlik ve Spor Bayramı kutlamaları için düzenlenen etkinlik kapsamında "Tarihi Yolculuk (Historic Journey) için takipte kalın!", "Sen de gitme hayali kurduğun yerleri TFT hashtag'ini kullanarak bizimle paylaşmayı unutma!” gibi ifadeler kullandığı içerik paylaşımları, takipçi etkileşimini arttırma imkanı oluşturmaktadır. Ayrıca, American Airlines'ın da salgın döneminde uçuş yapamayan müşterilerine; kendilerini uçak penceresinde gösteren profil çerçevesi kullanımı önerisinde bulunması ve Anneler gününe özel "Post your travel photo with mom in stories or feed and tag us (Annenizle seyahat fotoğraflarınızı bizi de etiketleyerek; gönderilerinizde veya hikayelerinizde paylaşın)" ifadesini içeren paylaşımı da etkileşim amaçlı marka iletişimi stratejisi kullanımı açısından önem taşımaktadır. Ancak, British Airways'in Instagram sayfasında bu özellikte bir içerik tespit edilmemesi; günümüzde sosyal ağlar aracılığ1 ile oluşan marka-takipçi etkileşimi olanaklarından; kriz döneminde firmanın etkin bir biçimde yararlanmadığını ortaya koymaktadır.

Tablo 4: Uluslararası Hava Yolu Şirketlerinin Instagram Sayfalarında Yer Alan İletilerin Covid-19 Salgını Dönemine Özel Olarak Kullanılan Marka İletişim Stratejileri Bağlamında Analizi

\begin{tabular}{|c|c|c|c|c|c|c|}
\hline \multicolumn{7}{|c|}{ Covid-19 Salgını Dönemi } \\
\hline \multirow[t]{2}{*}{ Havayolu Şirketi } & \multicolumn{2}{|c|}{ Türk Hava Yolları } & \multicolumn{2}{|c|}{ American Airlines } & \multicolumn{2}{|c|}{ British Airways } \\
\hline & $\mathbf{n}$ & $\%$ & $\mathbf{n}$ & $\%$ & $\mathbf{n}$ & $\%$ \\
\hline $\begin{array}{l}\text { Olumluluk } \\
\text { (Pozitiflik) }\end{array}$ & 27 & 47.4 & 21 & 42 & 5 & 25 \\
\hline $\begin{array}{l}\text { Şeffaflık/ } \\
\text { Sorumluluk Alma }\end{array}$ & 9 & 15.8 & 9 & 18 & 3 & 15 \\
\hline Destek Verme & 12 & 21.1 & 4 & 8 & 1 & 5 \\
\hline $\begin{array}{l}\text { Bağ kurma/ Ağlar } \\
\text { Oluşturma }\end{array}$ & 0 & 0 & 9 & 18 & 4 & 20 \\
\hline
\end{tabular}

İncelenen hava yolu şirketlerinin Covid-19 dönemine özel olarak Instagram kullanım biçimleri analiz edildiğinde ise; pozitif/olumlu mesaj verme üzerine temellenen içeriklerin niceliksel olarak daha fazla olduğu görülmektedir. Ancak, British Airways'ın mecrada kriz döneminde paylaştığı iletilerin azlığı; diğer hava yolu şirketlerine kıyasla salgınla mücadele için farklı stratejiler kullanma kapasitesini düşürmüştür. 
Instagram paylaşımlarında salgın döneminde, üç markanın da pozitif marka iletişim stratejisini; farklı oranlarla (THY: \% 47.4, AA: \%42, BA: \%25) birinci sirada kullandığı sonucuna ulaşılmıştır. THY'nin sayfasında bu stratejinin kullanıldığı içeriklere örnek olarak; toplumun birlik ve beraberliğini güçlendiren "Birlikte Başaracağız (WewillSuceedTogether)" ifadesinin farklı görsel ve videolarda kullanımı, Anneler Günü için özel yayınlanan videoda "Dünyalar kadar sevdiğimiz annelerimize bir an önce kavuşmak dileğiyle"; Ramazan Bayramı kutlama videosunda "Çok yakında kavuşacağız, masmavi göklerde yeniden birlikte uçacağız" ifadelerinin bulunması verilebilir. American Airlines'ın sayfasında ise pozitif mesaj veren içeriklere örnek olarak; "With our AA Team, we will get this together (AA takımımızla, bunu beraber atlacağız)" ifadesinin yer aldığ1 uçak görüntüsü, "Your AA Team's commitment to helping you during this unprecented time (Sizin Amerikan Airlines takımınızın, bu benzeri görülmemiş zamanda size yardım sözü var!)" ifadesinin yer aldığı müşteri yorumlarının görüntüleri verilebilir. British Airways'in Instagram sayfasında ise, Covid-19 döneminde paylaşılan içerik sayısı daha az olduğu için; markanın topluma olumlu mesaj verme stratejisini daha dolaylı olarak uygulayarak; virüsle mücadele üzerine yoğunlaştığı görülmektedir. Doğrudan mesaj verilen tek içerik ise; "We love you Britain and will see you very soon" (Seni seviyoruz İngiltere, kısa zamanda tekrar görüşeceğiz)" ifadesi içeren ve şirket çalışanlarının destek mesajlarını içeren videodur.

Şeffaflık/Sorumluluk alma stratejisi de üç hava yolunun Instagram sayfalarında, farklı oranlarda ortak olarak kullanılan bir kriz iletişimi stratejisidir. THY ve British Airways'in Instagram paylaşımlarında; uçuşların durması sonucu yaşanan krizle bağlantılı olarak seyahat planları ertelenen üyelerin statülerini koruması, işletmelerin yurt içi/yurt dışı biletleri açığa alma politikalarını güncellemesi, yurt dışında mahsur kalan vatandaşların ülkeye getirilmesi gibi içeriklere yer verilmesi; bu stratejinin uygulandığı örnekler arasında yer almaktadır. American Airlines'ın sayfasında ise; sorumluluk ve şeffaflık vurgusu içeren paylaşımlara örnek olarak; işletmenin "Our commitment to clean (Temizliğe sözümüz var!)" ifadesini kullandığı çoklu görsel paylaşımlarında hem temizlik hem de müşteri güvenliği temasını ön plana çıkarması ve "We are here for you on your journey (Yolculuğunuzda sizin için burdayız)" ifadesi ile müşteri odaklılı̆̆ını vurgulamas1 verilebilir. Bu strateji kullanımı \%18'lik ve \%15.8'lik oranlarla niceliksel olarak en fazla American Airlines ve THY'nin; \%15'lik oranla en az British Airlines'1n Instagram sayfasinda tespit edilmiştir.

Salgın döneminde, üç hava yolu firmasının Instagram paylaşımlarında ortak kullanılan bir diğer strateji ise; destek vermedir. Bu stratejinin uygulandığı içeriklere, THY ve British Airways sayfalarında sağlık çalışanlarının alkışlandığı etkinlik görüntüleri; American Airlines'ın sayfasında, New York Şehri Hastaneler Birliği'nde görev yapan sağlık çalışanlar için ücretsiz tatil etkinliği düzenlediği görsel ve videolar verilebilir. Bu strateji kullanımı, niceliksel olarak \%21.1'lik oranla en fazla THY'nin; \%5'lik oranla en az British Airways'in sayfasında tespit edilmiştir. Salgın sürecinde, bağ kurma/ağlar oluşturma stratejisi kullanımına ise toplam 9 ileti ile (\%18) en fazla yer veren hava yolu şirketinin; American Airlines olduğu sonucuna ulaşılmıştır. Şirketin bu stratejiyi uyguladığı içeriklere; "Our AA Team Members serve on local communities (AA takım üyelerimiz yerel topluluklarda hizmet veriyor), "Our AA team is honored to assembling more than 5.000 care packages for our AA heroes accross to country" (AA takımımız ülkenin farklı bölgelerine 5.000'den fazla yardım paketi götüren kahramanlarımızla onur duyuyor!)" gibi ifadeleri içeren görseller verilebilir. Ayrıca, pandemi döneminde AA'nın Instagram sayfasında karantinadaki askerlere gönderilen yardım paketlerinin teslimi, Amerikan Kızılhaçı için topladığı 2.000.000 dolarlık bağış duyurumu, Amerikan yemek bankalarına 81.000 dolar değerinde yapılan bağış açıklaması, filodaki uçakların yemek ve tıbbi malzeme taşıma amaçlı kargo uçaklarına dönüşümü gibi farklı faaliyetleri içeren görsel ve videolar tespit edilmiştir. İşletmenin yerel sivil toplum örgütleri ile gerçekleştirdiği iş birliklerine ise; paylaşımlarında etiketlediği Gary Sinice Foundation (Gary Sinice Vakfi) ile ortaklaşa gerçekleştirdiği yardım faaliyetleri verilebilir. British Airways; Instagram sayfasında sosyal sorumluluk temelli bağ kurma/ağ oluşturma stratejisinden \%20 
Uluslararası Havayolları Şirketlerinin Covid-19 Salgını Sürecinde Instagram'da Marka... 343

oranında yararlanmıştır. İşletmenin Instagram sayfasında bu stratejinin kullanıldığı içeriklere, İngiliz Kızıl Haçı, National Health Service System (İngiliz Ulusal Sağlık Sistemi) gibi kurumlarla yaptığı iş birlikleri duyurumları, gönüllü olarak çalışan personel görüntüleri ve hastanelere yapılan bağış açıklamaları verilebilir. Ancak, THY'nin sayfasında bu stratejinin kullanıldığı bir içerik tespit edilmemesi; etkileşimli sosyal ağlar aracıllğıyla Covid-19 döneminde, havayolu şirketinin sosyal sorumluluk temelli bağ kurma/ağlar oluşturma stratejisinin gerekliliklerini yerine getirmediğini göstermektedir.

Tablo 5: Covid-19 Salgını Öncesi ve Salgın Döneminde; Uluslararası Hava Yolu Şirketlerinin Instagram Sayfalarında Yer Alan İletilerin Marka Kişilik Boyutları Bağlamında Analizi

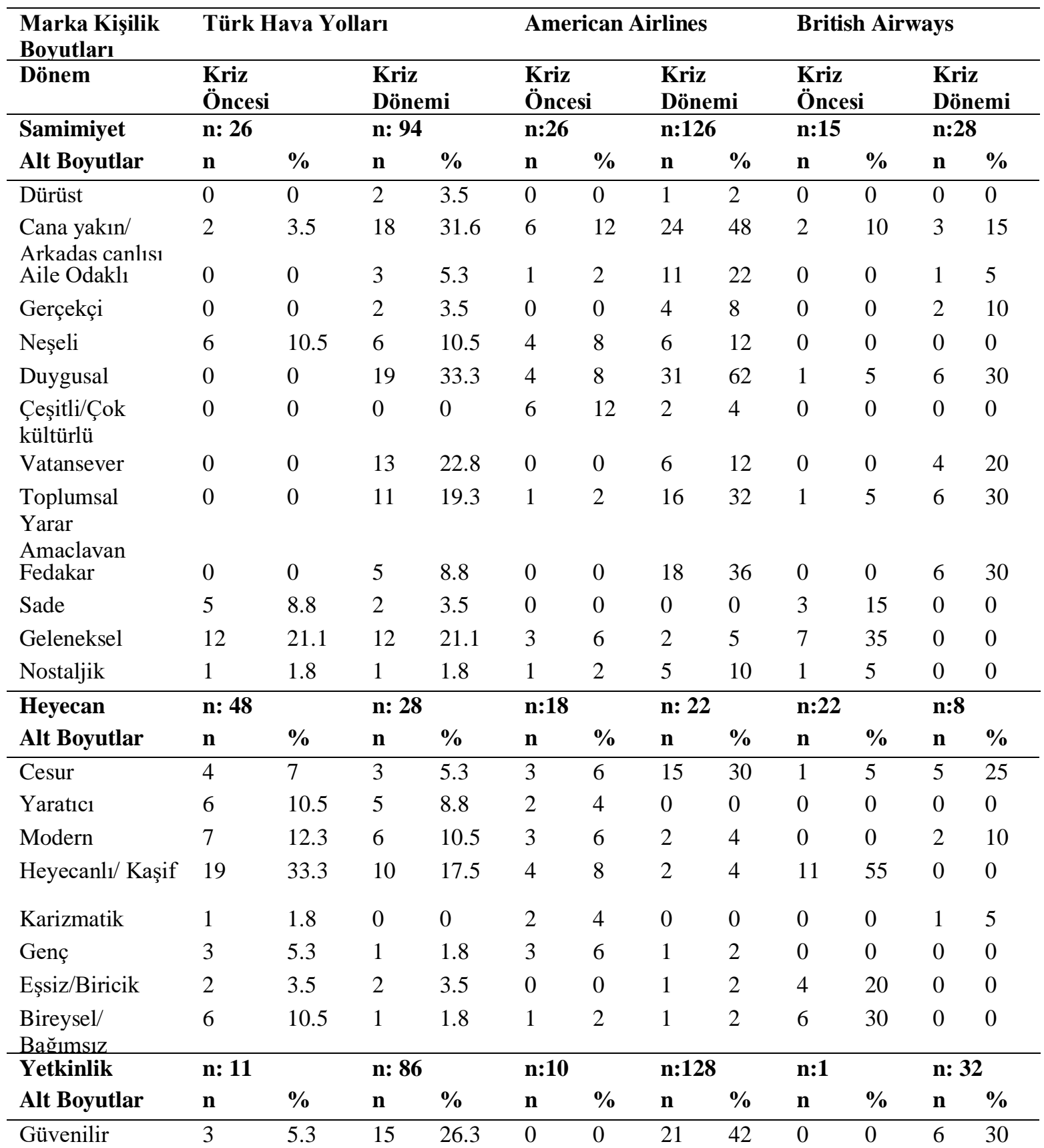




\begin{tabular}{|c|c|c|c|c|c|c|c|c|c|c|c|c|}
\hline Sorumlu & 0 & 0 & 18 & 31.6 & 0 & 0 & 24 & 48 & 1 & 5 & 7 & 35 \\
\hline Konforlu & 1 & 1.8 & 2 & 3.5 & 0 & 0 & 2 & 4 & 0 & 0 & 0 & 0 \\
\hline Başarılı & 1 & 1.8 & 6 & 10.5 & 3 & 6 & 7 & 14 & 0 & 0 & 0 & 0 \\
\hline Çalışkan & 2 & 3.5 & 11 & 19.3 & 2 & 4 & 21 & 42 & 0 & 0 & 4 & 20 \\
\hline Emniyetli & 1 & 1.8 & 10 & 17.5 & 0 & 0 & 13 & 26 & 0 & 0 & 5 & 25 \\
\hline Teknik & 1 & 1.8 & 2 & 3.5 & 0 & 0 & 3 & 6 & 0 & 0 & 1 & 5 \\
\hline Kurumsal & 2 & 3.5 & 10 & 17.5 & 5 & 10 & 24 & 48 & 0 & 0 & 7 & 35 \\
\hline Lider & 0 & 0 & 1 & 1.8 & 0 & 0 & 0 & 0 & 0 & 0 & 0 & 0 \\
\hline Temiz & 0 & 0 & 11 & 19.3 & 0 & 0 & 13 & 26 & 0 & 0 & 2 & 10 \\
\hline Seçkinlik & n: 11 & & n: 2 & & n: 0 & & n: 0 & & n: 5 & & n: & \\
\hline Alt Boyutlar & n & $\%$ & $\mathbf{n}$ & $\%$ & $\mathrm{n}$ & $\%$ & $\mathbf{n}$ & $\%$ & $\mathbf{n}$ & $\%$ & $\mathbf{n}$ & $\%$ \\
\hline Üst tabaka/ & 1 & 1.8 & 1 & 1.8 & 0 & 0 & 0 & 0 & 4 & 20 & 0 & 0 \\
\hline $\begin{array}{l}\text { Gösterisli } \\
\text { Çekici }\end{array}$ & 10 & 17.5 & 1 & 1.8 & 0 & 0 & 0 & 0 & 1 & 5 & 0 & 0 \\
\hline
\end{tabular}

Tabloda Covid-19 salgını öncesi ve salgın döneminde, incelenen hava yolu şirketlerinin Instagram sayfalarında yer alan iletilerde yansıttıkları temel marka kişilik boyutları, 4 temel kategori üzerinden analiz edilmiştir. Alt kişilik boyutu analizlerinde ise; ölçekte yer almasına rağmen, incelemede tespit edilmeyen boyutlara yer verilmemiştir. İncelenen içeriklerde; temel marka kişiliği boyutlarının altında yer alan alt boyutlar çoklu olarak yansıtabildiği için; ana kişilik özellikleri için yüzde hesaplaması yapılmamıştır.

Samimi marka kișiliği boyutu; Covid-19 öncesi dönemde; THY'nin sayfasında 5 farklı alt boyutta 26; AA'nın sayfasında 8 alt kategoride 94; BA'nın sayfasında 6 alt boyutta 15 kere; Covid19 salgını döneminde, THY'nin sayfasında 12 alt boyutta 92, AA'nın sayfasinda 12 alt boyutta 126; BA'nın sayfasında 7 alt boyutta 28 kez tespit edilmiştir. Kriz öncesi dönemde; THY ve British Airways'in sayfalarında cana yakınlık, sadelik, geleneksellik gibi alt boyutlar; tanıtımı yapılan şehrin/bölgenin özelliklerinin markaya atfedilmesi amacıyla kullanılmıştır. Kriz öncesi dönemde AA'nın sayfasında ise, ABD'nin çok uluslu yapısına bağlı olarak; farklı etnik kökenlere sahip personel kullanımı ile çok kültürlülük özelliğini vurgulaması önemli bir kişilik özelliği sunumudur. Ayrıca, bu dönemde, markanın personellerin hayatları ve başarıları ile ilgili duygusal hikayeler paylaşması da markanın çalışanlarını merkeze alarak; marka kişiliğini (geleneksel, sade, nostaljik vb.) oluşturmayı amaçladığını göstermektedir. Kriz döneminde ise; THY uçuş iptalleri ile ilgili yaşanan aksaklıklarla ilgili sorumluluğunu kabul ederek dürüst, yaşanan sorunların çözümüne yönelik gerçekçi; tüketici kullandığı görüntülerde aile odaklı; salgın sürecinde birliktelik vurgusu yaptığ 1 içeriklerde duygusal (Ramazan Bayramı kutlamalarında duygusal/nostaljik tema kullanımı vb.), fedakar (işine devam eden THY çalışanları görüntüsü vb.) ve toplumun yararını düşünen (yurt dışında mahsur kalan vatandaşların ülkeye getirilmesi vb.) marka kişilik özelliklerini yansıtmayı amaçlamıştır. AA'nın kriz döneminde ise, sosyal sorumluluk temelli marka iletişim stratejilerine ağırlık vermesine bağlı olarak; Amerikan askerlerine, yerel topluluklara ve hastanelere gönderilen yardımlar ve iş birliği görüntüleri ile duygusal, topluma fayda sağlayan, fedakâr ve vatansever marka kişiliğini daha ön plana çıktığı görülmektedir. Diğer hava yolu şirketlerine benzer biçimde, Covid-19 döneminde British Airways de, duygusal, topluma yarar sağlayan, fedakâr ve vatansever kişilik özelliklerini destek verdiği sosyal sorumluluk faaliyetlerinin görüntüleri, personel mesajları, yurttaşların ülkeye getirilmesi gibi farklı içerikler kullanarak pekiştirmeye çalışmıştır. Ayrıca, bu dönemde hem THY hem de BA Instagram paylaşımlarında daha önce kullanmadıkları bir tema olan "aile" vurgusuna da yer vermiştir.

Heyecanlı marka kișiliği boyutu, Covid-19 salgını öncesi dönemde THY'nin Instagram sayfasında 8 alt kategoride 48, AA'nın sayfasında 7 alt kategoride 18, BA'nın sayfasında 4 
Uluslararası Havayolları Şirketlerinin Covid-19 Salgını Sürecinde Instagram'da Marka... 345

kategoride 22 kere; Covid-19 salgını döneminde, THY'nin sayfasında 7 alt kategoride 28 kere; AA'nın sayfasında 6 kategoride 22, BA'nın sayfasında 3 kategoride 8 kere tespit edilmiştir. Hem British Airways hem de THY'nin Instagram sayfalarında, Covid-19 salgını döneminde heyecanlı marka kişilik özelliğinin sunum düzeyinin azalmasının nedeni; iki markanın da kriz öncesi temel marka stratejileri olan yer tanıtımı içeriklerinde keşif/heyecan/bağımsızlık temalarının ön plana çıkarılmasının değişikliğe uğramasıdır. Kriz döneminde ise; heyecanlı kişilik özelliği, cesaret teması üzerinden, işletmelerin kargo taşıma (sadece THY), vatandaşları ülkeye geri döndürme gibi fedakârlıkları ile ilişkilendirilmiştir. Ayrıca, THY'nin Instagram paylaşımlarında heyecan, keşif, bağımsızlık, özgürlük gibi duygular; takipçilere umut verme amacıyla bir gün uçuşların yeniden başlayacağını duyuran duygusal içeriklerle birlikte sunulmuştur. British Airways ise; modernlik, karizmatiklik gibi alt kişilik özellikleri üzerinden heyecan duygusunu personel görüntüleri ile yansıtmaya çalışmıştır. Kriz öncesi dönemde heyecanlı marka kişilik özelliğini çalışanlarının yaratıc1, modern, karizmatik görüntülerinin sunumu ile inşa eden American Airlines ise; salgın döneminde hem işletmenin hem de personelin yardım faaliyetlerine katılım görüntülerini paylaşarak; "cesur" marka algısı yaratmayı hedeflemiş ve "heyecanlı" marka kişilik özelliği ön plana çıkmıştır.

Yetkin kişilik boyutu ise; incelenen markaların sektördeki gücü ve uzmanlığı ile bağlantılı olup; krizi başarı ile yönetmeleri için önem taşımaktadır. Bu kişilik özelliğine; salgın öncesi dönemde THY'nin Instagram sayfasında 7 alt boyutta 11, AA'nın sayfasında 3 alt boyutta 10, BA'nın sayfasında sadece 1 kere; salgın döneminde, THY'nin sayfasında 10 alt boyutta 86; AA'nın sayfasında 9 alt boyutta 122 kere, BA'nın sayfasında 7 alt boyutta 32 kere verildiği sonucuna ulaşılmıştır. Üç markanın da sayfalarında; sadece salgın döneminde yer verilen kişilik boyutlarından en önemlisi temizlik olup; THY ve American Airlines uçaklarda ve havalimanlarında gerekli önlemlerin alındığına yönelik bilgilendirici görsel ve videolarda, bu kişilik özelliğinden yararlanılmıştır. British Airways'in sayfasında ise; sadece maske takan personel görüntüleri ile bu kişilik özelliğinin sınırlı ve dolaylı kullanımı; kriz döneminde hedef kitlenin artan güven ihtiyacının giderilmesi açısından önemli bir eksikliktir. Ayrıca, üç havayolunun paylaşımlarında, yurt dışından ülkeye getirilen vatandaşların görüntüleri (THYBritish Airways), uçuş iptalleri ile bilgilendirme yapılan videolar (THY-British Airways), uçuş öncesi güvenlik ve temizlik önlemleri (THY-American Airlines)- yardım kampanyası duyurumları (British Airways-American Airlines) gibi içeriklerle; salgın öncesi dönemden farklı olarak markaların güvenilir, sorumlu, emniyetli ve kurumsal çözümler üreten işletmeler olduğu algıs1 yaratılmaya çalışılmıştır. Seçkin marka kişilik boyutu sunumu, THY ve British Airways'in yer tanıtımı stratejisi ile bağlantılı olarak Covid-19 salgını öncesi dönemde sırasıyla 2 alt boyutta 11 ve 5 kere tespit edilmiștir. Covid-19 salgını döneminde ise; bu kişilik özelliğinin sadece THY'nin sayfasında 2 kere yer aldığı sonucuna ulaşılmıştır. Amerikan Airlines'ın Instagram paylaşımlarında ise bu kişilik özelliğinin hiç yansıtılmadığı tespit edilmiştir.

Üç markanın da Instagram sayfasında, kriz sonrası dönemde yansıtılma düzeyi en fazla yükselen marka kişilik boyutu “yeterlilik"dir. Çünkü, kriz dönemlerinde, tüketicilerin markalardan güvenilir, güvenli, kurumsal ve sorumlu davranışlar beklemesine bağlı olarak; işletmelerin bilgilendirici içerik ve çözüm önerileri sunması "yetkin" marka kişiliği özelliğini ön plana çıarmıştır. Ayrıca, milli duyguların ve topluluk bilincinin yükselmesine bağlı olarak; kriz öncesi döneme kıyasla "samimi" marka kişiliğinin; üç markanın Instagram sayfalarında yer alma düzeyi, Covid-19 pandemisi boyunca artmıştır. Yaşanan küresel kriz öncesi temel marka iletişim stratejilerini destinasyon tanıtımı üzerine kurgulayan British Airways'in ve THY'nin sayfalarında ise seçkinlik ve heyecan kişilik boyutlarının sunum düzeyinin azalması ise; Covid-19 salgını sürecinde hedef kitlenin değişen ihtiyaçları doğrultusunda, doğru bir iletişim stratejisidir. 
Tablo 6: Uluslararası Hava Yolu Şirketlerinin Instagram Sayfalarında Yer Alan İletilerin Covid-19 Salgını Dönemine Özel Olarak Kullanılan Marka Çağrışımları Bağlamında Analizi

\begin{tabular}{|c|c|c|c|c|c|c|}
\hline \multicolumn{7}{|c|}{ Covid-19 Salgını Dönemi } \\
\hline \multirow{2}{*}{$\begin{array}{l}\text { Havayolu Şirketi } \\
\text { Marka } \\
\text { Çağrışımları }\end{array}$} & \multicolumn{2}{|c|}{ Türk Hava Yolları } & \multicolumn{2}{|c|}{ American Airlines } & \multicolumn{2}{|c|}{ British Airways } \\
\hline & $\mathbf{n}$ & $\%$ & $\mathbf{n}$ & $\%$ & $\mathbf{n}$ & $\%$ \\
\hline Eğlence & 0 & 0 & 0 & 0 & 0 & 0 \\
\hline Güç & 5 & 8.8 & 11 & 22 & 5 & 25 \\
\hline Güvenlik & 10 & 17.5 & 13 & 26 & 5 & 25 \\
\hline $\begin{array}{l}\text { Olumluluk/ } \\
\text { Pozitiflik }\end{array}$ & 27 & 47.4 & 21 & 42 & 5 & 25 \\
\hline İlgili/Yardımcı & 22 & 38.6 & 27 & 54 & 8 & 40 \\
\hline Güvenilirlik & 15 & 26.3 & 21 & 42 & 6 & 30 \\
\hline
\end{tabular}

Araştırma sonucunda, Covid-19 döneminde özel olarak ilgili havayollarının Instagram sayfalarında kullanılan çağrışımların; yansıtılan marka kişiliği boyutları ve uygulanan marka iletişim stratejileri ile bağlantılı olduğu tespit edilmiştir. Ayrıca, salgın döneminde; hiçbir marka eğlence çağrışımına yer vermemiştir. Güç çağrışımı; markanın krizle başa çıkma potansiyelini temele almaktadır. Instagram'da bu çağrışımın kullanıldığ i içerikler; vatandaşların ülkeye getirilme süreci (THY ve British Airways) ve sosyal sorumluluk kampanyalarına verilen mali ve insani destek (American Airlines ve British Airways) ile bağlantılıdır. Güç marka çağrışımı kullanımı, sayısal olarak en fazla AA'nın Instagram paylaşımlarında (toplam 11 ileti) tespit edilmiştir. Güvenlik ve güvenilirlik çağrışımları ise; havayolu şirketlerinin salgınla mücadele döneminde aldığı tedbirler olarak temizlik işlemleri (American Airlines ve THY), uçuş haklarının korunması (üç hava yolu), konulu içerikleri kapsamaktadır. İki çağrışım da sayısal olarak en yüksek düzeyde American Airlines'ın (sırasıyla 13 ve 21 ileti) paylaşımlarında kullanılmıştır. Olumlu ve pozitif marka çağrışımları ise; toplumsal birlik beraberliği güçlendiren mesajlar, umut dolu paylaşımlar ve özel gün kutlamaları konulu iletileri içermektedir. Olumlu ve pozitif çağrışım taşıyan içerikler ise, en fazla Türk Hava Yolları'nın (toplam 21 ileti) Instagram sayfasında paylaşıımıştır. Markanın sürece yönelik ilgili ve yardımcı bir rol üstlendiği içerikler ise; niceliksel olarak en fazla American Airlines'ın (toplam 27 ileti) sayfasında tespit edilmiştir. İncelenen hava yollarının, takipçilerinde olumlu hisler oluşturmak amaçlı paylaştıkları içerikler, bilgilendirme mesajları, sosyal sorumluluk faaliyetleri ve etkinlikler; işletmelerin salgınla mücadele döneminde ilgili/yardımcı rolünü güçlendirmiştir. Bu bağlamda, Covid-19 dönemine özel marka rolünü; güç, güven, güvenilirlik ve ilgili/yardımcı gibi farklı kalıplar üzerine başarılı bir biçimde inşa eden firmanın American Airlines olduğu sonucuna ulaşılmaktadır. THY ise; süreçteki marka rolünü "olumluluk" üzerinden kurgulamakla birlikte; diğer marka çağrışımlarına da niceliksel olarak yüksek düzeyde yer vermiştir. İlgili marka çağrışımları; Covid-19 döneminde British Airways'in Instagram sayfasında da tespit edilmekle birlikte; bu dönemde markanın sınırlı paylaşım gerçekleştirmesi, toplumun 
Uluslararası Havayolları Şirketlerinin Covid-19 Salgını Sürecinde Instagram'da Marka... 347

kendisinden beklentilerini etkileşimli bir sosyal medya platformu aracılığ 1 ile sunma kapasitesini kısıtlamıştır.

Tablo 7: Covid-19 Salgını Öncesi ve Salgın Döneminde; Uluslararası Hava Yolu Şirketlerinin Instagram Sayfalarında Yer Alan İletilerin Biçimsel Analizi

\begin{tabular}{|c|c|c|c|c|c|c|c|c|c|c|c|c|}
\hline \multirow{3}{*}{\begin{tabular}{|l}
$\begin{array}{l}\text { Havayolu } \\
\text { Şirketi }\end{array}$ \\
Dönem \\
\end{tabular}} & \multicolumn{4}{|c|}{ Türk Hava Yolları } & \multicolumn{4}{|c|}{ American Airlines } & \multicolumn{4}{|c|}{ British Airways } \\
\hline & \multicolumn{2}{|c|}{$\begin{array}{l}\text { Kriz } \\
\text { Öncesi }\end{array}$} & \multicolumn{2}{|c|}{$\begin{array}{l}\text { Kriz } \\
\text { Dönemi }\end{array}$} & \multicolumn{2}{|c|}{$\begin{array}{l}\text { Kriz } \\
\text { Öncesi }\end{array}$} & \multicolumn{2}{|c|}{$\begin{array}{l}\text { Kriz } \\
\text { Dönemi }\end{array}$} & \multicolumn{2}{|c|}{$\begin{array}{l}\text { Kriz } \\
\text { Öncesi }\end{array}$} & \multicolumn{2}{|c|}{$\begin{array}{l}\text { Kriz } \\
\text { Dönemi }\end{array}$} \\
\hline & $\mathbf{n}$ & $\%$ & $\mathbf{n}$ & $\%$ & $\mathbf{n}$ & $\%$ & $\mathbf{n}$ & $\%$ & $\mathbf{n}$ & $\%$ & $\mathbf{n}$ & $\%$ \\
\hline Görsel & 13 & 22.8 & 3 & 5.3 & 3 & 6 & 28 & 56 & 12 & 60 & 4 & 20 \\
\hline Video & 9 & 15.8 & 32 & 56.1 & 9 & 18 & 10 & 20 & 0 & 0 & 4 & 20 \\
\hline $\begin{array}{l}\text { Marka Kimliği } \\
\text { Bileşenleri } \\
\text { Kullanımı }\end{array}$ & 10 & 17.5 & 30 & 52.6 & 6 & 12 & 8 & 16 & 11 & 55 & 6 & 30 \\
\hline Bağlantıllık & 0 & 0 & 3 & 5.3 & 0 & 0 & 2 & 4 & 9 & 45 & 0 & 2 \\
\hline
\end{tabular}

Covid-19 öncesi ve sonrası dönemde, ilgili havayolu şirketlerinin Instagram paylaşımlarının biçimsel yapısı incelendiğinde; görsel ve video kullanım düzeylerinin değiştiği görülmektedir. Salgın döneminde THY'nin görsel kullanım düzeyi \%22.8'den \%5.3'e düşerken; video kullanım oranı \%15.8'ten \%56.1' yükselmiştir. Bu dönemde, British Airways'in de görsel kullanım oranı \%60'tan \%20'ye düşerken; salgın öncesi hiç video kullanmayan marka, pandemi boyunca \%20 oranında video kullanmıştır. Bu sonuç, iki markanın da Covid-19 öncesi süreçte, temel marka iletişim stratejilerini, mecranın görsel ağırlıklı yapısını merkeze alarak yer tanıtımı üzerine kurgulaması ile ilintilidir. İki hava yolu şirketinin de Covid-19 döneminde, toplumsal birlikte ve beraberliğe odaklanan, ulusal/dini bayramları/özel günleri kutlayan (sadece THY); pozitif kriz yönetim stratejisini merkeze alan içerik paylaşım düzeyinin yükselmesi, video paylaşım oranını da arttırmıștır. American Airlines'ın ise; kriz döneminde görsel kullanım oranı \%6'dan \%56'ya; video kullanım oranı ise \%18'den \%20'ye yükselmiş̧ir. Bu sonuç, işletmenin Covid-19 salgını öncesi dönemde; personel kullanımı üzerine odaklanarak, çalışanlarının yaşam tarzı, başarıları, uzmanlığını vurgulayan videolara sayısal olarak daha yüksek düzeyde yer vermesine karşın; kriz döneminde marka iletişim stratejilerini, tüketici kullanımı ve sosyal sorumluluk faaliyetlerinin duyurumu çerçevesinde genişletmesi ile bağlantılıdır. $\mathrm{Bu}$ artışta, işletmenin Instagram'da çalışanlarının yardım faaliyetlerine katıldığı fotoğraflar ve güvenlik/temizlik uyarılarını içeren görüntüler paylaşması da etkili olmuştur.

İçeriklerde logo/slogan kullanım düzeyi analiz edildiğinde ise; hem THY'nin, hem de American Airlines'ın Instagram sayfalarında, kriz dönemi paylaşılan iletilerin fazlalığına bağlı olarak; bu öğelerin kullanım düzeyinin sırasıyla \%17.5'den \%52.6'ya; \%12'den \%16'ya yükseldiği görülmektedir. Ancak, incelenen hava yolu şirketleri arasında, kriz öncesi dönemde; marka bilinirliğini/hatırlanabilirliğini arttıracak temel kimlik öğeleri olarak logo ve slogan kullanımı, en düşük düzeyde American Airlines sayfasında tespit edilmiştir. British Airways'in Instagram 
paylaşımlarında ise, kriz öncesi dönemde $\% 55$ oranında saptanan logo/slogan kullanım düzeyi; içerik sayısının düşmesine bağlı olarak, Covid-19 pandemisi döneminde düşmüştür. Ancak, işletmenin hem kriz öncesi/hem kriz döneminde iletilerinde niceliksel olarak logo/slogan kullanımının fazlalığı; görsel ağırlıklı bir mecra olarak marka kimliği oluşumu amacıyla mecrayı etkin kullandığını göstermektedir. Kriz öncesi dönemde, THY ve American Airlines'ın Instagram'da diğer sosyal medya platformlarına veya web sitelerine bağlantı oluşturmadığı tespit edilmiştir. Bu sonuç; iki işletmenin de sosyal ağın bağlantılılık özelliğinden etkin yararlanmadığını göstermektedir. Buna karşın, pandemi öncesinde British Airways Instagram sayfasında "Visit (ziyaret et)" ifadesini kullanmış; uçuş güzergahları ile bağlantılı olarak takipçilerini web sayfasına yönlendirmiş ve anlaşmalı olduğu otellerin linklerini paylaşmıştır. Bu kullanım biçimi, markanın takipçi kitlesini satın alma davranışına yönlendirme potansiyelini yükseltmektedir. Kriz döneminde ise; THY ve British Airways şirketleri değişen uçuş politikaları ile ilgili bilgi vermek için; Instagram takipçilerini www.turkishairlines.com ve ba.com/confidence adreslerine yönlendirmiştir. American Airlines ise, bu dönemde takipçilerini fotoğraflarını uçak penceresine yerleştirmelerine sağlayan bir uygulama linkine, bio (tanıtım) bölümü aracıllğı ile yönlendirirken; elite statü kullanım haklarının uzatılmasını içeren bir duyuruyu yine bio (tanıtım) bölümünde yer alan bir link aracılığıyla gerçekleştirmiştir.

Tablo 8: Covid-19 Salgını Öncesi ve Salgın Döneminde; Uluslararası Hava Yolu Şirketlerinin Instagram Sayfalarında Yer Alan İletilerin Etkileşimsel Analizi

\begin{tabular}{|c|c|c|c|c|c|c|}
\hline \multirow{2}{*}{$\begin{array}{l}\text { Havayolu } \\
\text { SSirketi } \\
\text { Dönem }\end{array}$} & \multicolumn{2}{|c|}{ Türk Hava Yolları } & \multicolumn{2}{|c|}{ American Airlines } & \multicolumn{2}{|c|}{ British Airways } \\
\hline & $\begin{array}{l}\text { Kriz } \\
\text { Öncesi }\end{array}$ & $\begin{array}{l}\text { Kriz } \\
\text { Dönemi }\end{array}$ & $\begin{array}{l}\text { Kriz } \\
\text { Öncesi }\end{array}$ & $\begin{array}{l}\text { Kriz } \\
\text { Dönemi }\end{array}$ & $\begin{array}{l}\text { Kriz } \\
\text { Öncesi }\end{array}$ & $\begin{array}{l}\text { Kriz } \\
\text { Dönemi }\end{array}$ \\
\hline & $\mathbf{n}$ & $\mathbf{n}$ & $\mathbf{n}$ & $\mathbf{n}$ & $\mathbf{n}$ & $\mathbf{n}$ \\
\hline $\begin{array}{l}\text { Beğeni/ } \\
\text { Görüntüleme } \\
\text { Sayıs1 }\end{array}$ & 1.174 .543 & 9.535 .310 & 585.742 & 784.610 & 82.496 & 406.876 \\
\hline Yorum Sayıs1 & 13.939 & 25.921 & 2.983 & 8.418 & 1.448 & 5.095 \\
\hline
\end{tabular}

Tabloda görüldüğ̈ üzere, hem Covid-19 salgını öncesi, hem de salgın döneminde Instagram içeriklerinin beğeni/görüntüleme/ yorum etkileşim düzeyi en yüksek olan hava yolu şirketi Türk Hava Yolları; en düşük olan hava yolu firması British Airways'dir. THY ve American Airlines şirketlerinin salgın döneminde paylaştıkları içerik sayısının artışına bağlı olarak; etkileşim düzeyleri de yükselmiştir. Ancak, British Airways'in Covid-19 sürecinde daha az ileti paylaşmasına rağmen; hem yorum/hem de beğeni etkileşim düzeyinin arttığ1 görülmektedir. Etkileşimin yükselmesinde, firmanın kriz öncesi dönemden farklı olarak, mecrada video paylaşımı gerçekleştirmesi etkili olmuştur. Bu bağlamda, Covid-19 döneminde sosyal medya tüketim düzeyinin artışı doğrultusunda, tüketici ile bağ kurma amacıyla içerik paylaşım sayısını arttıran THY ve American Airlines'ın mecrayı etkin kullandığı, British Airways'in ise; kısıtlı içerik paylaşımı ile Instagram'ın etkileşimli yapısından tam anlamıyla yararlanamadığı görülmektedir.

\section{Sonuç ve Öneriler}

Covid-19 salgının bir krize dönüşmesinden, en çok etkilenen sektörlerin başında, tüm dünyada uygulanan seyahat kısıtlamalarına bağlı olarak hava yolu şirketleri gelmektedir. Yaşanan kriz sürecinde; uluslararası hava yolu şirketleri için takipçilerle etkileşim oluşturmak, tüketicileri bilgilendirmek; alışılan müşteri deneyimini devam ettirmek gibi farklı amaçlarla sosyal medya platformlarının önemi artmıştır. Bu çalışmada, farklı marka iletişim stratejilerinin uygulanmasına ve marka kişiliği/marka çağrışımları boyutlarının sunumuna görsel ağırlıklı yapısı ile daha fazla imkan tanıyan bir sosyal medya platformu olarak Instagram'da, Türk Hava Yolları, American Airlines ve British Airways'in paylaşımları karşılaştırmalı olarak analiz edilmiştir. Araştırma 
Uluslararası Havayolları Şirketlerinin Covid-19 Salgını Sürecinde Instagram'da Marka... 349

sonucunda ise; incelenen markaların mecrayı kullanma biçimleri açısından kriz öncesi ve kriz dönemi arasında önemli farklar tespit edilmiştir.

Araştırma sonucunda, British Airways hariç incelenen tüm havayolu şirketlerinin salgın döneminde paylaştıkları içerik sayısının yükselmesine bağlı olarak, potansiyel müşterileri/ takipçileri ile etkileşimi sürekli tutmak amacıyla mecrayı etkin kullandıkları sonucuna ulaşılmıştır. Covid-19 sürecinde, BA'nın resmi Instagram hesabında içerik paylaşım oranının düşmesi; kriz döneminde maliyetsiz ve etkileşimli bir mecra aracılığıyla, marka-tüketici etkileşimin sürdürülmesi olanağından, markanın yeterince yararlanmadığını ortaya koymaktadır.

Araştırmanın "İncelenen hava yolu şirketlerinin Instagram paylaşımlarında kriz öncesi ve kriz dönemlerinde kullandıkları marka iletişim stratejileri nasıl farklılaşmıştır?" biçiminde geliştirilen birincil sorusu; şu şekilde cevaplanmıştır. Kriz dönemi öncesinde bilgilendirici iletişim stratejisi kullanımına üç hava yolu şirketinin de Instagram hesaplarında hiç verilmemesine rağmen; kriz döneminde THY'nin sayfasında \%12.3, American Airlines'ın sayfasında \%14, British Airways'nın sayfasında ise \%10 oranında yer verildiği tespit edilmiştir. Araştırma sonuçlarına göre, imaj odaklı marka iletişim stratejisi; hem kriz öncesi/hem kriz döneminde üç markanın da Instagram'da gerçekleştirdiği çalışmaların temelini oluşturmaktadır. THY ve BA sırasıyla \%21.1 ve \%55'lik oranlarla "yer tanıtımı" üzerine imaj kurgulamasını gerçekleştirirken, AA \%20'lik oranla personel kullanımını ön plana çıkarmıştır. Ancak, kriz döneminde, üç markanın da imaj odaklı marka iletişim stratejileri değişmiştir. THY ve BA' nın Instagram içeriklerinde "yer tanıtım" stratejisi yerine farklı oranlarla, personel/tüketici/hizmeti temsil eden bir araç olarak uçak kullanımı gibi farklı stratejiler uyguladığ1 tespit edilmiştir. AA ise; kriz öncesi dönemde olduğu gibi imaj oluşturma amacıyla personel kullanımı stratejisine yüksek düzeyde yer vermekle birlikte, alt marka iletişim stratejilerini sosyal sorumluluk ve tüketici kullanımı gibi farklı uygulamalar üzerinden çeşitlendirmiş̧ir. Bu sonuç, kriz döneminde değişen tüketici beklentilerine, incelenen markaların Instagram'da farklı temel ve alt marka iletişim stratejileri kullanarak uyum sağladığını göstermektedir.

Çalışmanın "İncelenen hava yolu şirketlerinin Instagram paylaşımlarında Covid-19 salgınına özel uygulanan marka iletişim stratejilerinin benzerlik ve farklılıkları nelerdir?" biçiminde geliştirilen ikincil sorusu ise şu şekilde cevaplanmıştır. Üç markanın da, Instagram sayfalarında paylaştıkları içeriklerde ilk sırada değişen oranlarda, topluma olumlu mesajlar verme stratejisini kullandığ 1 görülmektedir. Çalışmada, tespit edilen bir diğer önemli benzerlik ise; şeffaflık/sorumluluk alma (süreçle ilgili sorumluluğuna kabul ederek çözüm önerileri geliştirme) ve destek verme (sağlık çalıșanlarının alkıșlanması gibi sosyal amaçlı içerik paylaşımı) stratejilerinin değişen oranlarda ortak kullanımıdır. Temel fark ise; THY'nin Instagram'da; incelenen diğer iki markadan farklı olarak sosyal sorumluluk temelli işbirliği paylaşımlarına yer vermemesidir. $\mathrm{Bu}$ sonuç, toplumun iktisadi işletmelerden salgın döneminde artan daha sorumlu davranma beklentisinin, THY tarafindan etkileşimli bir sosyal medya platformu aracılı̆̆ıyla karşılanamadığını ortaya koymaktadır.

Araştırmanın, "İncelenen hava yolu şirketlerinin Instagram paylaşımlarında kriz öncesi ve kriz dönemlerinde yansıttıkları temel marka kişilik boyutları nasıl farklılaşmıştır?” biçiminde oluşturulan üçüncül sorusu ise şu şekilde cevaplanmıştır. Kriz öncesi dönemde, markaların Instagram paylaşımlarında yüksek düzeyde yansitılan kişilik boyutları, "samimiyet" (THY ve AA:26; BA:15) ve "heyecan" (THY:48, AA: 18, BA: 22) olarak tespit edilmiştir. Bu sonuç, THY ve BA'nın "yer tanıtım" stratejisi ile bağlantılı olarak paylașımlarında uçuș gerçekleștirdikleri şehirlere yönelik "keşif, merak" duygusunu ortaya çıkaracak özellikte ileti paylaşımları ile bağlantılıdır. American Airlines ise; personeli merkeze alan "samimi" kişilik özelliğine paylaşımlarında daha fazla yer vermiştir. Buna karşın, kriz öncesi dönemde, üç markanın da çok düşük düzeyde yer verdiği "yetkin" kişilik özelliği, Covid-19 pandemisinde (THY:86, AA: 128, 
BA:32), en yüksek düzeyde yansitılan kişilik boyutuna dönüşmüştür. Ayrıca, üç hava yolu şirketinin de; Instagram paylaşımlarında "samimi" marka kişiliği sunum düzeyi (THY:94; AA: 126, BA:28) yükselmiştir. Kriz döneminde tespit edilen bir diğer önemli farklılık ise; AA'nın aktif destek verdiği sosyal sorumluluk faaliyetlerine bağlı olarak inşa etmeye çalıştığ "cesur" marka kişiliğiyle bağlantılı olarak "heyecan" boyutunun bu markanın paylaşımlarında daha ön plana çıkmasıdır. Ayrıca, THY kriz öncesinden farklı olarak "seçkin" kişilik sunumunu azaltırken; British Airways bu özelliğe pandemi sürecinde hiç vermemiştir. Bu sonuç, kriz dönemlerinde toplumun markalardan güvenilir, kurumsal ve sorumlu davranışlar gerçekleştirmelerini talep etmesine ve milli duygular/ topluluk/toplum bilincinin yükselmesine bağlı olarak; üç hava yolu şirketinin de süreci doğru yönettiğini ortaya koymaktadır.

Araştırmanın "İncelenen hava yolu şirketlerinin Instagram paylaşımlarında Covid-19 salgınına özel kullanılan marka çağrışımlarının benzerlik ve farklılıkları nelerdir?" biçiminde geliştirilen dördüncü sorusu ise şu şekilde cevaplanmıştır. İlgili hava yolu şirketlerinin sayfalarında hastalık süreci ile ilgili kullanılan çağrışımlar açısından tespit edilen temel benzerlik; hiçbir markanın eğlence temasına odaklanmaması ve "olumluluk" temasının değişen oranlarda kullanılan birincil çağrışım olmasıdır. Ayrıca, üç işletmenin de krize özel "ilgili/yardımcı" rolünü Instagram paylaşımları aracılığıyla inşa etmeye çalıştığı görülmektedir. Temel farklılık ise; THY'nin daha yüksek oranda pozitif, AA'nın güçlü/güvenli/güvenilir marka çağrışımlarına yer vermesine karşın; British Airways'in sayfasında içerik sayısı azlığına bağlı olarak, sürece özel temalara yeterince yer verilememesidir. Bu sonuç, üç markanın da Covid-19 salgınına özel marka çağrışımları kullanarak farklı oranlarda da olmakla birlikte, tüketicilerin taleplerine bağlı olarak değişen rollerini inşa etmeye çalıştığını göstermektedir.

Çalışmanın "İncelenen hava yolu şirketlerinin Instagram sayfalarında yer alan iletilerin kriz öncesi ve kriz döneminde etkileşim düzeyi nasıll bir farklılaşmıştır?” biçiminde geliştirilen beşincil sorusu ise şu şekilde cevaplanmıştır. Hem Covid-19 salgını öncesi, hem de salgın döneminde, Instagram'da beğeni/görüntüleme/yorum etkileşim düzeyi en yüksek firmanın THY (önce 1.174.543 beğeni/görüntüleme, 13.939 yorum; kriz dönemi: 9.535 .310 görüntüleme/beğeni; 25.921 yorum), orta düzeyde olan markanın AA (önce: 585.742 beğeni/görüntüleme, 2.983 yorum; kriz dönemi: 784.610 beğeni/görüntüleme, 8.418 yorum) en düşük işletmenin British Airways (önce 82.496 beğeni/görüntüleme, 1.448 yorum; kriz dönemi: 406.876 beğeni/görüntüleme, 5.095 yorum) olduğu tespit edilmiştir. Ayrıca, kriz döneminde üç markanın da Instagram sayfasında, etkileşim düzeyi yükselmiştir. Etkileşim ve paylaşılan içerik sayısına bağlı olarak, bu sonuçlar sosyal medya tüketim alışkanlıklarının artışı doğrultusunda; tüketici ile bağ kurmak için içerik paylaşım sayısını arttıran THY ve American Airlines'ın daha yüksek etkileşim oluşturmasına bağlı olarak; British Airways'e kıyasla mecrayı daha etkin kullandığını ortaya koymaktadır.

Han vd. (2018)'in vurguladığı üzere, kriz dönemlerinde markaların iletişim stratejilerini farklılaştırması/döneme özel stratejiler uygulaması ve yansıtılan marka kişiliği boyutlarının dönüşümü gibi değişikliklere duyulan ihtiyaç doğrultusunda, Covid-19 salgını döneminde incelenen hava yolu şirketlerinin Instagram'da marka iletişim faaliyetlerini sürece uygun bir biçimde dönüştürmesi doğru bir iletişim stratejisidir. Sheridan vd. (2020:6)'in Covid-19 sürecinde tüketicilerin markalardan beklentilerinin değiştiğini gösteren araştırması temele alındığında ise; çalışma sonucunda Instagram aracılığıyla Covid-19 salgını ile mücadele sürecinde incelenen hava yolu şirketlerinin olumlu, işbirlikçi, sorumluluk sahibi ve destek verici stratejiler kullanarak; içeriklerini güç, güvenlik, pozitiflik, güvenilir gibi temalar üzerine inşa etmeleri doğru bir stratejidir. Ayrıca, mecranın bu amaçlarla kullanımı, üç markanın da sürece yönelik ilgili/yardımcı, güvenilir marka rolünü güçlendirme potansiyeli taşımaktadır. Ancak, Kotler (2005:33)'ın vurguladığı üzere; kriz dönemlerinde müşteri değerinden taviz verilmemesi ve alışık olunan marka deneyiminin sürdürülmesi gerekliliği göz önüne alındığında; British Airways hava yolu şirketinin Covid-19 sürecinde paylaşım sayısını azaltmasının; stratejik marka iletişim faaliyetleri açısından bir eksiklik oluşturduğu sonucuna ulaşılmaktadır. Bu bağlamda, kriz öncesi ve kriz döneminde 
Uluslararası Havayolları Şirketlerinin Covid-19 Salgını Sürecinde Instagram'da Marka... 351

Instagram paylaşımları incelenen havayolu şirketleri özelinde, işletmelerin mecrayı daha etkin kullanabilmeleri açısından şu öneriler geliştirilmiştir.

- Türk Hava Yolları, Covid-19 pandemisi gibi küresel olarak etkili olabilecek bir sağlık krizinde, incelenen diğer iki hava yolu şirketine benzer biçimde, mecrada sorunla mücadele ile ilgili sosyal sorumluluk faaliyetleri içeren paylaşımlara yer vererek; toplumla bağ kurmalı ve sosyal ağlar oluşturmalıdır.

- American Airlines, hem normal, hem de potansiyel kriz dönemlerinde Instagram'da marka bilinirliğini/hatırlanabilirliğini arttıracak temel kimlik öğeleri olarak logo ve slogan kullanımı düzeyini yükseltmelidir.

- American Airlines ve Türk Hava Yolları, mecrada kriz harici dönemlerde Instagram'ın bağlantılılık özelliğinden yararlanarak; potansiyel müşteri kitlelerini doğrudan satın alma davranışına yönlendirebilecek link kullanımından yararlanmalıdir.

- Çalışmada, Covid-19 pandemisi döneminde içerik paylaşım sayısı ve etkileşim düzeyi en düşük olan havayolu şirketi olarak tespit edilen British Airways ise, benzer bir sağlık krizi durumunda markanın unutulabilmesi, tüketici hassasiyetlerinin göz ardı edilmesi/alışılan deneyimin sağlanmaması gibi olumsuz sonuçlara neden olabileceği için mecrada içerik paylaşımını sürdürmelidir.

- Ayrıca, British Airways'in, olası bir küresel sağlık ve hava yolu krizi durumunda, Instagram'da ulusal ve küresel özel gün kutlamaları gerçekleştirmeli, tüketicilerin gözünde "yeterli" marka kişiliğini inşa edebilmek "temizlik" vurgusunu ön plana çıkarmalı, daha yüksek sayıda içerik paylaşımı ile toplumun ihtiyaçlarının giderilmesi için ilgili/yardımcı ve güvenilir marka rolünü pekiştirmeli, etkileşim düzeyini yükseltebilecek video gibi farklı multimedya bileşeni kullanımını arttırması gerekmektedir.

Covid-19 salgını gibi, küresel olarak farklı toplumların sağlı ve refahını tehdit eden bir kriz dönemlerinde, yaşanan süreçten etkilenme düzeyi yüksek olan hava yolu gibi sektörlerde faaliyet gösteren işletmelerin; Instagram gibi marka kişiliğini yansıtmaya ve farklı marka iletişim stratejilerini kullanmaya imkân tanıyan platformları aktif kullanması gerekmektedir. Bu tarz kriz dönemlerinde, paylaşılan içeriklerde marka iletişim stratejileri ve çağrışımlarının, takipçi etkileşimi arttırabilecek bir biçimde yeniden yapılandırılması da yerinde bir strateji olacaktır. Bu araştırma, Covid-19 krizinden etkilenen diğer sektörlerin ve başka havayolu firmalarının Instagram veya diğer sosyal medya platformlarını kriz öncesi, kriz ve kriz sonrası dönemlerde kullanım biçimlerinin tespitini amaçlayan diğer çalışmalara yön gösterici olacaktır. Böylece, farklı sosyal medya platformları ve sektörlerde sosyal medya bileşenlerinin, Covid-19 salgını ile bağlantılı olarak kullanım biçimleri karşılaştırmalı olarak tartışılabilecektir.

\section{Kaynakça}

Aaker, D. A. (2004). Leveraging the corporate brand. California Management Review, 46(3), 6-18. https://doi.org/10.1177/000812560404600301

Aaker, J. L. (1997). Dimensions of brand personality. Journal of Marketing Research, 34(3) 347356. https://doi.org/10.1177/002224379703400304 
ACI (2020). The impact of COVID-19 on the airport business. Airports Council International. https://aci.aero/wp-content/uploads/2020/03/200401-COVID19-Economic-ImpactBulletin-FINAL-1.pdf.

Akdenizli, B. (2012). "Gazete Haberciliğinde İçerik Çözümleme Yöntem ve Tekniği: Sunum ve Temsil Üzerine Bir Uygulama ve Değerlendirme.” İletișim Bilimlerinde Araștırma Yöntemleri Yazılı Metin Çözümleme. (Der.) Ö. Güllüoğlu. Ütopya Yayınevi. 133-162.

Akdoğan, A. A. \& Cingöz, A. (2009). "Kurumsal itibar ve kriz yönetimi: Kurumsal itibarı korumada kriz iletişimin rolü." Kriz Yönetimi. (Der.) Haluk Sümer ve Helmut Pernsteiner. İstanbul Bilgi Üniversitesi Yayınları. 3-33.

Alexander, D. E. (2013). Social media in disaster risk reduction and crisis management. Science and Engineering Ethics, 20, 717-733. https://doi.org/10.1007/s11948-013-9502-z

Aslan, E. (2016). Markaların kriz dönemlerinde sosyal medya kullanımı stratejileri: Gezi Park1 olayları sürecinde Twitter üzerine bir inceleme. Gümüşhane Üniversitesi Illetişim Fakültesi Elektronik Dergisi, 4 (2), 505-533. https://doi.org/10.19145/gujofoc.64515

Ataman, G. (2001). İşletme yönetimi: Temel kavramlar ve yeni yaklaşımlar. Türkmen Kitabevi.

Auffermann, K. (2010). Toyota talks about social media and the recall crisis. Public Relations Tactics, 17(6), 19. https://doi.org/ 10.1057/crr.2013.6

Austin, L., Liu, B. F., \& Jin, Y. (2012). How audiences seek out crisis information: exploring the social-mediated crisis communication model. Journal of Applied Communication Research, 40, 188-207. https://doi.org/ 0.1080/00909882.2012.654498

Aziz, A. (2008). Sosyal bilimlerde araştırma yöntemleri ve teknikleri. Nobel Yayınları.

Babür-Tosun, N. (2010). Illetişim temelli marka yönetimi. Beta Yayınları.

Bat, M. \& Yurtseven-Turan, Ç. (2014). Sosyal medyada kurumsal kriz yönetimi: Onur Air örneği. Gümüşhane Üniversitesi Iletişim Fakültesi Elektronik Dergisi, 2 (3), 197-223. https://doi.org/10.19145/guifd.74720

Benoit, W. L. (2018). Crisis and image repair at United Airlines: Fly the unfriendly skies. Journal of International Crisis and Risk Communication Research, 1 (1),11-26. https://doi.org/10.30658/jicrcr.1.1.2

Baxter, L.A. \& Babbie, E.R. (2004). The basics of communication research. Thompson and Wadsworth.

Berelson, B. (1952). Content analysis in communication research. Free Press.

Bridgeman, R. (2008). "Crisis communication and the net: Is it just about responding faster... or do we need to learn a new game?" Crisis communication: Practical PR strategies for reputation management and company survival. (Der.) P. F. Anthonissen. Kogan Page. 169177.

Can, H. (2005). Organizasyon ve yönetim. 7. Basım. Siyasal Kitapevi.

Canpolat, N. \& Şahiner, N. (2017). "İmaj restorasyon teorisi mesaj stratejileri çerçevesinde Samsung Galaxy Note 7 güvenlik krizinin incelenmesi". The Turkish Online Journal of Design, Art and Communication, 7 (2), 213-225.

Cervera-Taulet, A.vd. (2013). Influence of advertising on brand personality in the airline sector: The case of Spain. J. Travel Tour. Mark. 30, 445-454. https://doi.org/10.1080/10548408.2013.803390 
Uluslararası Havayolları Şirketlerinin Covid-19 Salgını Sürecinde Instagram'da Marka... 353

Çetinkaya A. \& Özdemir, Z. (2014). Sosyal Ağların Pazarlama Disiplinleri İçinde Kullanımı: Instagram Üzerine Bir İnceleme. Dijital İletişim Etkisi Bildiriler Kitabı. Dijital İletişim Etkisi Konferans1. İstanbul: 16-17 Ekim 2014.

Cheng, Y. (2016). How social media is changing crisis communication strategies: Evidence from the updated literature. Journal of Contingencies and Crisis Management, 2 (22), 1-11. https://doi.org/ 10.1111/1468-5973.12130

Cho, S., \& Huh, J. (2010). Content analysis of corporate blogs as a relationship management toolnull. Corporate Communications: An International Journal, 15(1), 30-48. https://doi.org/.10.1108/13563281011016822

Coombs, W. T. (2008). Crisis communication and social media. http://www.instituteforpr.org/crisis-communication-and-social-media/

Coombs, W. T (2010). "Parameters for crisis communication", The Handbook of Crisis Communication. (Der). W. Timothy Coombs ve Sherry J. Holladay. Wiley Blackwell. 1753.

Cohn, R. (2014, March 13). How social media is elevating airline crisis communication. https://www.socialfresh.com/how-social-media-is-elevating-airline-crisis-communication/

Davis, J. A. (2011). Rekabetçi başarı, markalaşma nasıl değer katar? Çev. Uğur Mehter. BrandAge Yayınları.

De Vries, L., vd. (2012). Popularity of brand posts on brand fan pages: An investigation of the effects of social media marketing. Journal of Interactive Marketing, 26, 83-91. http://dx.doi.org/10.1016/j.intmar.2012.01.003

Dinçer, Ö. (1998). Stratejik yönetim ve işletme politikası. 5. Basım. Beta Yayınları.

Duğan, Ö. (2018). Sosyal medya kaynaklı krizlerin imaj restorasyon teorisi açısından örnek olaylar üzerinden incelenmesi. Akdeniz İletişim Dergisi, 29, 293-313. https://doi.org/10.31123/akil.396418

Ginsberg, K. (2015). Instabranding: Shaping the Personalities of the Top Food Brands on Instagram. The Elon Journal of Undergraduate Research in Communications, 6(1): 78-91.

Glasscock, J. (2004). The Jasper dragging death: Crisis communication and the community $\begin{array}{lllll}\text { newspaper. } & \text { Communication } & \text { Studies, } & 55 & \text { (1), }\end{array}$ http://dx.doi.org/10.1080/10510970409388604

Gonzalez-Herrero, A., \& Smith, S. (2008). Crisis communications management on the Web: how internet-based technologies are changing the way public relations professionals handle business crises. Journal of Contingencies and Crisis Management, 16, 143-153. http://dx.doi.org/10.1111/j.1468-5973.2008.00543.x

Goor, M.A. (2012). Instamarketing”: a content analysis into marketing on Instagram. [Unpublished master's thesis]. Universiteit Van Amesterdam. http://dare.uva.nl/cgi/arno/show.cgi?fid=449011

Han, J., Hi Sung, Y. \& Kim, D. H. (2017). Brand Personality Usage in Crisis Communication in Facebook, Journal of Promotion Management, 24(6), 798-819 https://doi.org/10.1080/10496491.2017.1408526

Hurk, A. M. (2013). Social media crisis communications: preparing for, preventing, and surviving a public relations \#Fail. Pearson Education. 
IATA (2020, June 9). Economic Per formance of the Airline Industry. The International Air Transport Association. https://www.iata.org/en/iata-repository/publications/economicreports/airline-industry-economic-performance-june-2020-report/

IATA (2020, March 3). IATA Updates COVID-19 Financial Impacts -Relief Measures Needed. The International Air Transport Association. https://www.iata.org/en/pressroom/pr/2020-03-05$01 /$

IATA (2020, April 14). COVID-19 Updated Impact Assessment. The International Air Transport Association. https://www.iata.org/en/iata-repository/publications/economic-reports/covidfourth-impact-assessment/

Jensen, K. B. (2011). "New Media, Old Methods, Internet Methodologies and the Online/Offline Divide." Çev. Yiğit Yavuz. Medya ve İzleyici Bitmeyen Tartışma. (Der.) Şahinde Yavuz. Vadi Yayınları. 55-83.

Ki, E., \& Hon, L. C. (2006). Relationship maintenance strategies on Fortune 500 company web sites. Journal of Communication Management, 10(1), 27-43. https://doi.org/ $10.1108 / 13632540610646355$

Kim, S., vd.. (2016). Self-mocking crisis strategy on social media: Focusing on Alibaba chairman Jack $\mathrm{Ma}$ in China. Public Relation Review, 42(5): 903-12. https://doi.org/10.1016/j.pubrev.2016.10.004

Kotler, P. (2005). A'dan Z'ye pazarlama. MediaCat.

Kotsi, F. \& Valek, N.S. (2018). Flying with Nicole Kidman or Jennifer Aniston? Brand funnel stages' influence on brand personality. Journal of Travel \& Tourism Marketing, 35 (3), 365-376. https://doi.org/10.1080/10548408.2017.1360232

Lindsay, B. R. (2011). Social media and disasters: current uses, future options and policy considerations. Journal of Current Issues in Media \& Telecommunications, 2, 287-297.

Lipsman, A., vd. (2012). The Power of "Like". Journal of Advertising Research, 52, 40-52. http://dx.doi.org/10.2501/JAR-52-1-040-052

Lukaszewski, E. J. (1997). Establishing individual and corporate crisis communication standarts: the principles and protocols. Public Relation Quarterly, 42 (3), 7-14.

Mangold, W. G. \& Faulds, D. J. (2009). Social media: The new hybrid element of the promotion mix. Business Horizons, 52, 357-365. http://dx.doi.org/10.1016/j.bushor.2009.03.002

Murphy, L., vd. (2007). Using brand personality to differentiate regional tourism destinations. Journal of Travel Research, 46, 5-14. https://doi.org/10.1177/ 0047287507302371

OAG Schedules Analyzer, (2019). Direct flights only. Data is for w/c 23 July $2019 v$ w/c 24 July 2018. https://www.oag.com/schedules-analyser.

Orange Insights. (2010, October 18). Community during crisis: what governments can learn from the Boulder community's usage of social media during the Boulder Fire. http://www.slideshare.net/BrandBehavior/orange-insightsteryspataroboulderfiresocialmediaanalysisemergencypreparednesscrowd sourcing.

Özgen, Ö. \& Elmasoğlu, K. (2016). Sosyal Medya ve Marka İletişimi: Havayolu Şirketlerinin Twitter Kullanımına Yönelik Bir Araştırma. Illetişim Kuram ve Araştırma Dergisi. 43,181202.

Öztürk, M. C. (2015). "Sosyal Medya ve Kurumsal İletişim". Dijital İletişim ve Yeni Medya. (Der.) M. Canan Öztürk. Anadolu Üniversitesi Yayınları. 120-152 
Uluslararası Havayolları Şirketlerinin Covid-19 Salgını Sürecinde Instagram'da Marka... 355

Park, J.-W., vd. (2004). The effect of airline service quality on passengers' behavioural intentions: A Korean case study. Journal of Air Transport Management, 10, 435-439. https://doi.org/10.1016/j.jairtraman.2004.06.001

Peltekoğlu, F. (2007). Halkla ilişkiler nedir? Genişletilmiş 5. Baskı. Beta Yayınları.

Ramaseshan, B. \& Tsao, H.-Y. (2007). Moderating effects of the brand concept on the relationship between brand personality and perceived quality. Journal of Brand Management, 14 (6), 458-466. https://doi.org/10.1057/palgrave.bm.2550090

Roshan, M., Warren, M., \& Carr, R. (2016). Understanding the use of social media by organizations for crisis communication. Computers in Human Behavior, 63, 350-361. https://doi.org/10.1016/j.chb.2016.05.016

Ruggiero, A., \& Vos, M. (2014). Social media monitoring for crisis communication: process, methods and trends in the scientific literature. Online Journal of Communication \& Media Technologies, 4, 105-130. https://doi.org/10.29333/ojcmt/2457

Ryschka, vd. (2016). The effect of social media on reputation during a crisis event in the cruise line industry, International Journal of Hospitality \& Tourism Administration, 17:2, 198-221, https://doi.org/10.1080/15256480.2015.1130671

Sheridan, A. vd. (2020, March 26). Covid-19 The Creative Fightback. https://www.ipsos.com/sites/default/files/ct/publication/documents/2020-04/ipsos-creativefightback.pdf.

Schultz F., vd. (2011). Is the medium the message? Perceptions of and reactions to crisis communication via twitter, blogs and traditional media. Public Relations Review, 37(1): 20-27. https://doi.org/10.1016/j.pubrev.2010.12.001

Spence, P. R., vd. (2006). Gender and age effects on information seeking after 9/11. Communication Research Reports, 23, 217e233. http://dx.doi.org/10.1080/ 08824090600796435

Statista (2020, July 24). Leading Countries Based on Instagram Audience Size as of July 2020. https://www.statista.com/statistics/578364/countries-with-most-instagram-users/

Stephens, K. (2010, October 13). Social media during crisis response: five general lessons for emergency managers. Idisaster2.0. http://idisaster. wordpress.com/2010/10/20/socialmedia-during-crisis-response-some- general-lessons.

Taecharungroj, V. (2016). Starbucks' marketing communications strategy on Twitter. Journal of Marketing Communications, 1-19. http://dx.doi.org/10.1080/13527266.2016.1138139

Tafesse, W. (2015). Content strategies and audience response on Facebook brand pages. Marketing Intelligence \& Planning, 33, 927-943. http://dx.doi.org/10.1108/MIP-07-2014-0135

Tafesse, W. (2016). An experiential model of consumer engagement in social media. Journal of Product \& Brand Management, 25, 424-434. http://dx. doi.org/10.1108/JPBM-05-20150879.

Tafesse, W. \& Wien, A. (2017). A framework for categorizing social media posts. Cogent Business and Management, 4, 1-22. http://dx.doi.org//10.1080/23311975.2017.1284390

Ulmer, R. R. (2001). Effective crisis management through established stakeholder relationships. Management Communication Quarterly, 14, 590-615. https://doi.org/10.1177/0893318901144003 
Uca Özer, S. \& Kayaalp Ersoy G. (2012). Türkiye'de Faaliyet Gösteren Havayolu Şirketlerinin Marka Kişiliklerini Belirlemeye Yönelik Bir Araştırma. Anatolia: Turizm Araştırmaları Dergisi, 23(2), 173-186.

Uztuğ, F. (2003). Markan kadar konuş marka iletişimi stratejileri. 4. Baskı. MediaCat Yayınları.

Vassollo A.J., vd. (2018). Junk food marketing on Instagram: content analysis. JMIR Public Heal Surveill. 4(2):e54. 1-11 https://doi.org/10.2196/publichealth.9594

Veil, S. R., vd. (2011). A work-in-process literature review: Incorporating social media in risk and crisis communication. Journal of Contingencies and Crisis Management, 19(2), 110-122. http://dx.doi.org/10.1111/j1468-5973.2011.00639.x

Wang, Y. (2014). Brand crisis communication through social media: A dialogue between brand competitors on Sina Weibo. Corporate Communications: An International Journal, 21 (1), 56-72. https://doi.org/ 10.1108/CCIJ-10-2014-0065

Wang, Y. \& Dong, C. (2017). Applying social media in crisis communication: A quantitative review of social media-related crisis communication research from 2009 to 2017. International Journal of Crisis Communication, 1, 29-37.

Wattanacharoensil, W., \& Schuckert, M. (2015). How global airports engage social media users: A study of Facebook use and its role in stakeholder communication. Journal of Travel \& Tourism Marketing, 32(6), 656-676. http://dx.doi.org/10.1080/10548408. 2014.955245

Westerman, D., vd.2014). Social media as infor-mation source: Recency of updates and credibility of information. Journal of Computer-Mediated Communication, 19, 171-183. http://dx.doi.org/10.1111/ jcc4.12041.

We are Social (2020, April 23). April Global Stats Report. https://wearesocial.com/blog/2020/04/digital-around-the-world-in-april-2020.

WHO (2020, April 27). WHO Timeline - COVID-19. https://www.who.int/news-room/detail/27-042020-who-timeline---covid-19

Yoo, E., vd. (2016). Evaluating information diffusion speed and its determinants in social media networks during humanitarian crises. Journal of Operations Management. 45, 123-133. https://doi.org/10.1016/j.jom.2016.05.007 